\title{
Five factors for urban sustainability - exploring influences on municipal strategic planning
}

\section{Paul Fenton}

Division of Environmental Technology and Management

Department of Management and Engineering

Linköping University, SE-581 83 Linköping, Sweden

www.liu.se 
(C) Paul Fenton, 2014

Linköping Studies in Science and Technology

Licentiate Thesis No. 1646

ISBN: 978-91-7519-390-8

ISSN: 0280-7971

Printed by LiU-Tryck, Linköping 2014

Cover: Paul Fenton

Distributed by:

Linköping University

Department of Management and Engineering

SE-581 83 Linköping, Sweden 


\section{Sammanfattning}

På senare år har konsensus att hållbar stadsutveckling är kritisk för jordens och mänsklighetens framtid vuxit fram. Effekterna av befolkningstillväxten och människors påverkan på miljön syns runt om i världen, och är inte bara märkbar i många stora städer utan även i mindre städer, på landsbygden och till och med i obebodda områden. Därför står hållbar stadsutveckling i fokus i denna licentiatavhandling.

Avhandlingen fokuserar på kommunorganisationens roll i hållbar stadsutveckling och organisering av processerna att utveckla strategier och politik som syftar till hållbar stadsutveckling. Utöver det har även deltagandet av andra aktörer i sådana processer studerats. Avhandlingen avslutas genom att presentera ett nytt begrepp som kan underlätta strategisk planering, nämligen "de fem faktorerna".

De fem faktorerna är kommuners/aktörers kapacitet att arbeta för hållbar stadsutveckling; deras mandat att driva hållbar stadsutveckling; tillgängliga resurser som får disponeras; processernas omfattning och önskat utfall; och den individuella- och kollektiva viljan att uppnå hållbar stadsutveckling. Femfaktorsbegreppet skulle kunna bidra till framtidsanalys av hållbara stadsutvecklingsprocesser, i såväl planering som genomförande. De fem faktorerna bygger på slutsatser från licenciatsavhandlingens tre artiklar samt en syntes av dessa.

Den första och andra artikeln presenterar resultaten från ett forskningsprojekt som granskade processerna kring framtagande av energi- och klimatstrategier i kommuner som deltog i det svenska nationella programmet Uthållig kommun. I första artikeln ligger fokus på organiseringen av processerna, medan erfarenheterna av deltagande intressenter reflekteras över i den andra artikeln. De två artiklarna bygger på befintliga teoretiska ramverk och presenterar en mängd empiri från fem kommuner, som erhållits genom t.ex. dokumentstudier, intervjuer. Utifrån detta har slutsatser dragits kring för- och nackdelar i utformningen av planeringsprocesser för energi- och klimatstrategier, t.ex. att processer som involverar intressenter tidigt även resulterar i strategier som är mer omfattande.

I den tredje artikeln presenteras resultaten av en multidisciplinär litteraturundersökning. Vetenskapliga artiklar som handlar om "hållbar stadsutveckling" och publicerade under perioden 2011-2012 står i fokus. Artikeln syftar till att bättre förstå hur hållbar stadsutveckling tillämpas i praktiken, hur det beaktas, hur det representeras i den akademiska litteraturen, samt vilka effekter som uppstår på grund av denna representation, såsom t.ex. ett brist på analys av governance processer för hållbar stadsutveckling i kommuner. Medan de första artiklarna behandlar praktiken med hänsyn till specifika teoretiska perspektiv, syftar den tredje artikeln till att ge en överblick och identifiera utmaningar och möjligheter inom forskningen för hållbar stadsutveckling. Tillsammans illustrerar de tre artiklarna ett flertal aspekter som påverkar utvecklingen av kommunernas strategiska arbete för hållbar stadsutveckling - de fem faktorerna. 



\section{Abstract}

In recent decades, there has been increasing consensus that sustainable urban development is critical to the future of human societies and planetary systems. The effects of population growth and the environmental impacts of human activities are evident around the world, observable not only in the rapid urbanisation of many large cities, but also in small-medium conurbations, rural communities, and even uninhabited areas. For this reason, sustainable urban development is the theme of this licentiate thesis.

The thesis focuses on the role of municipal organisations in sustainable urban development, the ways in which processes to develop strategies and policies addressing urban sustainability are organised, and how other stakeholders participate in such processes. The thesis concludes by presenting a new conceptual framework that aims to inform such processes - the "five factors" influencing strategic planning for urban sustainability in municipalities.

The five factors concern the capacity of municipalities and others to act for urban sustainability; their mandate to do so; the resources available to them; the scope of their processes and intended outcomes; and their will, individually and collectively, to pursue urban sustainability. The five factors concept may aid future analysis of urban sustainability processes, both in planning and implementation. The five factors are based upon the findings of the three appended papers and the synthesis of their results in this thesis.

The first and second papers present studies of energy and climate strategy planning processes in Swedish municipalities active in a national programme, the Sustainable Municipality (Uthållig kommun). Paper 1 focuses upon the organisation of processes to develop energy and climate strategies, whereas Paper 2 reflects upon the experiences of participating stakeholders in such processes. The two papers build upon existing theoretical frameworks and present empirical data from case studies of five municipalities, based on document studies, interviews and comparative analysis, in order to make conclusions about the advantages and disadvantages of variations in the form and composition of energy and climate planning (e.g. that early involvement of stakeholders results in more comprehensive strategies).

In contrast, Paper 3 presents analysis of a multidisciplinary sample of academic journal articles addressing "urban sustainability" and published during the period 2011-2012. As such, this paper focuses on how urban sustainability is practiced, observed and represented in academic literature, and considers different issues that arise as a consequence (e.g. a lack of analysis of urban sustainability governance processes in municipalities). Whereas Papers 1 and 2 observe practice, making insights with reference to specific theoretical perspectives, Paper 3 provides overview and identifies wider challenges and opportunities for research on the theme of urban sustainability. Together, the three papers highlight a number of issues that influence the development of municipalities' strategic work for urban sustainability - the five factors. 



\section{Acknowledgements}

This thesis completes two and a half years of research at Linköping University, during which time I've been fortunate to meet many interesting people and travel to new places. I would like to thank my supervisors, Olof Hjelm and Sara Gustafsson, for their advice and support during this time, as well as my co-authors and colleagues at the Division of Environmental Technology and Management.

The thesis builds upon work in the Sustainable Energy and Climate Strategies (HEKSA) project. I thank the Swedish Energy Agency for their support of this project. Similarly, I thank the Sparbanksstiftelsen Alfas Internationella Stipendiefond för Linköpings Universitet for the scholarship which enabled me to present results from this study at the $3^{\text {rd }}$ International Urban Research Symposium at the 2012 ICLEI World Congress.

I first began studying Local Agenda 21 in Swedish municipalities under the tuition of Professor Richard Stren at the University of Toronto. Subsequently, my personal journey took me from England to Spain, on to Uppsala and then to work in Freiburg, Germany, for the ICLEI European Secretariat. I wish to thank the late Stefanie Lay, as well as Monika Zimmermann and my other ex-colleagues, for giving me the opportunity to work with them and a global network of municipalities.

I owe a debt of gratitude to Göran Carstedt and others at the Clinton Foundation for providing me with the opportunity to continue working with cities and sustainable development, whilst establishing myself in Sweden. Similarly, I wish to thank Kristina Birath and other colleagues and clients from my time at WSP, particularly the staff of the Environment and Health Administration of the City of Stockholm. These, and other professional experiences, have contributed to my personal development and provide the context for my choice to pursue Ph.D. studies in this field.

I wish to thank my parents and family for their love, support and patience. I especially wish to thank Naghmeh joonam and Darya khosgele, who fill my world with joy. 



\section{List of Appended Papers}

1. Fenton, P., Gustafsson, S., Ivner, J., Palm, J., (forthcoming). Sustainable energy and climate strategies: lessons from planning processes in five Swedish municipalities. Submitted to Journal of Cleaner Production (decision pending).

2. Fenton, P., Gustafsson, S., Ivner, J., Palm, J., (forthcoming). Stakeholder participation in municipal energy and climate planning - experiences from Sweden. Submitted to Local Environment (decision pending).

3. Fenton, P., (forthcoming). Exploring the state of the art in urban sustainability literature what do recent articles reveal? Submitted to Local Environment (decision pending).

\section{My Contribution to the Papers}

Papers 1 and 2. Lead author, major contribution to data collection and analysis in a collaborative research project.

Paper 3. Sole author responsible for research design and analysis. Comments and support provided by Olof Hjelm and Sara Gustafsson.

\section{Related Publications}

Fenton, P., Gustafsson, S., Ivner, J., Palm, J., (2012) Sustainable Energy and Climate Strategies: lessons from planning processes in five municipalities. Linköping: Linköping University. 



\section{Contents}

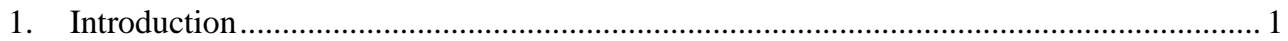

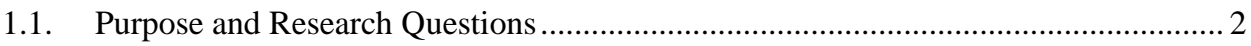

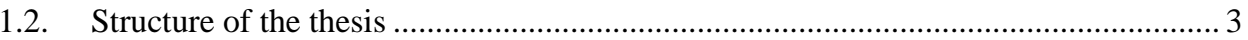

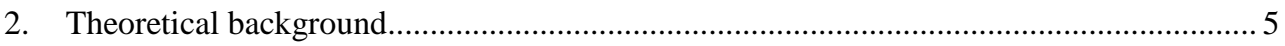

2.1. Studying sustainability in an urban context......................................................... 5

2.2. Defining terms: municipalities, municipal organisations and stakeholders .............. 6

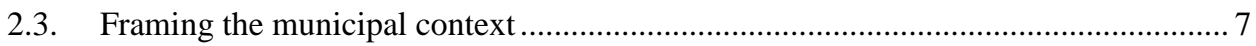

2.4. Focusing on the Swedish context ….................................................................. 8

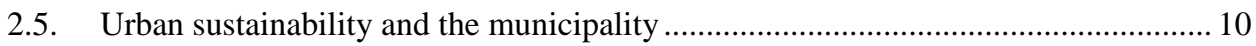

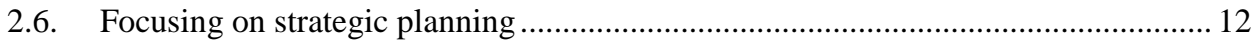

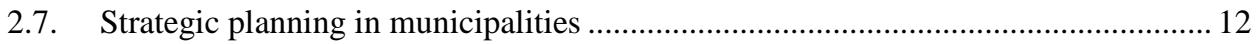

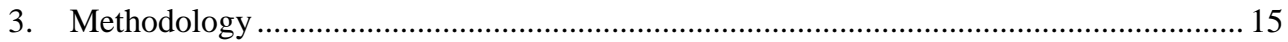

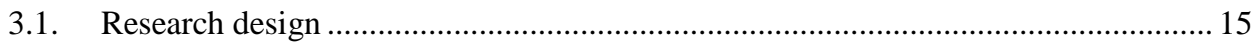

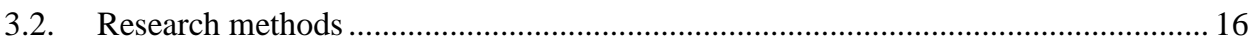

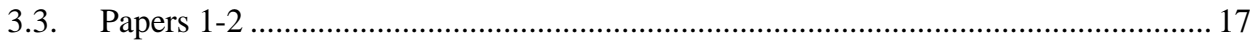

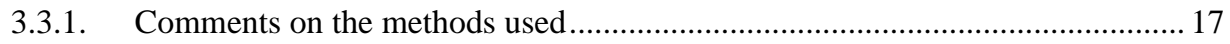

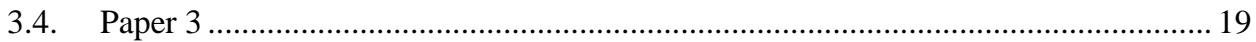

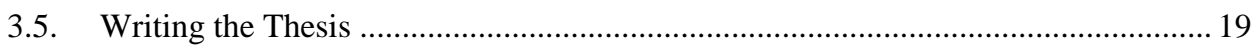

3.6. Limitations and reflections on choice of methods ...................................................... 20

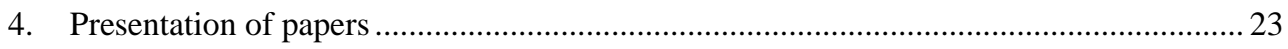

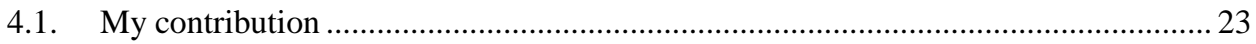


4.1.1. Paper 1 - Sustainable energy and climate strategies: lessons from planning processes in five Swedish municipalities.

4.1.2. Paper 2 - Stakeholder participation in municipal energy and climate planning experiences from Sweden

4.1.3. Paper 3 - Exploring the state of the art in urban sustainability literature - what do recent articles reveal?

5. Results .25

5.1. Papers 1-2 25

5.2. Paper 3

5.3. Relationship of Papers 1-2 with Paper 3 30

5.4. Relationship of Paper 3 with Papers 1-2 31

6. Synthesis discussion. 33

7. Conclusions... 37

8. Future Research 39

9. References 41 


\section{Introduction}

Rapid urbanisation, population growth and increasing concern about the environmental impacts of human activities have in recent decades led to the emergence of sustainable urban development as an influential, controversial and contested concept.

Many initiatives seeking to promote sustainable urban development have, particularly in the period since the Kyoto Protocol was signed, emphasised efforts to mitigate and adapt to climate change (Lundqvist and Biel, 2007). As such, actions to reduce greenhouse gas emissions or transform energy systems to enable more efficient, low-carbon societies are considered important components of sustainable urban development. In Europe, for example, municipal organisations are encouraged to develop and implement strategic energy action plans for their municipalities, in order to reduce greenhouse gas emissions, reduce energy use or increase energy efficiency (European Commission, 2010).

Similarly, in Sweden, to support development of municipal energy and climate strategies, the Swedish Energy Agency initiated a national programme known as the Sustainable Municipality (Uthållig kommun, Swedish Energy Agency, 2011). The three phases of the programme have seen municipalities exchange ideas and technical knowledge on energy and climate issues, as well as develop strategies and action plans aiming to reduce their use of energy and emission of greenhouse gases. The central role of the municipal organisation in energy and climate planning makes it a key object of study, yet it is also important to consider the ways in which other stakeholders are involved in processes to develop energy and climate strategies (see e.g. Ivner et al, 2010).

Thus, this thesis considers experiences from several municipalities participating in the Sustainable Municipality programme, with particular focus on how the processes to plan and develop energy and climate strategies were organised (Paper 1), and the ways in which stakeholders participated in such processes and their experiences of participation (Paper 2). These two papers build upon and develop existing theoretical frameworks and present empirical data, gathered using a variety of methods, from five municipalities, in order to make conclusions about the advantages and disadvantages of variations in the form and composition of energy and climate planning.

The thesis also presents analysis of a multidisciplinary sample of academic journal articles addressing "urban sustainability" published during the period 2011-2012 (Paper 3). Whereas Papers 1 and 2 observe practice, making insights with reference to specific theoretical perspectives, Paper 3 provides overview and reflects upon the study and practice of urban sustainability. This paper considers issues including the methods used and themes covered by articles, as well as challenges and opportunities in the field of urban sustainability.

Together, the results of the three papers inform the findings of this thesis, which are presented in the Synthesis Discussion. This thesis juxtaposes the findings of Paper 3 with those of 
Papers 1 and 2, exploring links and contrasts between the practical attempts to contribute to urban sustainability of several Swedish municipalities - observed in energy and climate planning in Papers 1 and 2 - and a range of other practical and theoretical contributions to urban sustainability presented by scholars included in the literature sample for Paper 3 . The theoretical and empirical material upon which the three papers are based is then used to propose a conceptual framework for analysis of urban sustainability processes - the five factors.

\subsection{Purpose and Research Questions}

The thesis is exploratory and aims to contribute to improving understanding of factors influencing municipal organisations when organising and conducting processes to develop urban sustainability strategies, thereby benefiting researchers and practitioners alike. To do so, the thesis will synthesise findings from three papers in order to develop a conceptual framework that may provide new insights into the practical organisation of strategic planning processes in Swedish municipalities.

More specifically, the thesis will consider examples from processes to conceptualise, define, plan and implement energy and climate strategies and reflect upon the experiences of stakeholders involved in such processes and the implications of stakeholder participation for energy and climate planning. The thesis also considers the framing of urban sustainability in recent scientific journal articles, providing an overview of methods, themes, challenges and opportunities for both researchers and practitioners.

The thesis proceeds by presenting the results from three papers. Each of the three papers has its own purpose and aim, as reflected in the Research Questions (RQs):

1. How are processes to develop energy and climate strategies organised in Swedish municipalities?

2. How do stakeholders participate in energy and climate planning in Swedish municipalities?

3. What do recent scientific journal articles on urban sustainability reveal about the study and practice of urban sustainability?

Each RQ is responded to by the paper with the corresponding number. The papers provide the basis for the proposition of factors influencing municipal urban sustainability processes and their outcomes (see Synthesis Discussion). 


\subsection{Structure of the thesis}

This thesis proceeds as follows: the Theoretical background presents a discussion of the main themes and focus of the thesis, including a general overview of relevant scholarly discussions. Subsequently, the Methodology used to design and conduct studies is presented, including discussion of the scope and limitations of the methodology and reflections on the approach used. The next chapter is a Presentation of Papers in which the main themes and findings of the studies are summarised, followed by Results from the papers.

This forms the basis for a Synthesis discussion which analyses the results and develops a new conceptual framework for future study - the five factors. Conclusions and ideas for Future Research are followed by a list of References used when writing the thesis. The complete manuscripts for the three papers are included as Appendices. 


\section{Theoretical background}

In this section, the theoretical background to the thesis and papers is presented. A brief discussion concerning the relevance of Studying sustainability in an urban context leads into a section Defining terms, which outlines definitions of some key concepts used in the thesis. The next section outlines issues to consider when Framing the municipality context and Focusing on the Swedish context, which is discussed in Papers 1 and 2. A summary of these discussions follows in Urban sustainability and the municipality, prior to sections on the implications of Focusing on strategic planning and Strategic planning in municipalities. These sections complement the summary by emphasising the specific contribution the thesis and papers make.

\subsection{Studying sustainability in an urban context}

The well-documented, observed norm of unsustainable development (e.g. Crutzen and Stoermer, 2000; Levidow and Oreszczyn, 2012; UN-Habitat, 2011; WCED, 1987) provides the immediate context for this thesis. Knowledge and acceptance of unsustainable development provides the impetus for efforts promoting sustainable development. Sustainable development is a multi-faceted, anthropocentric concept (Jacobs, 1999; Connelly, 2007) that is innately linked to the patterns of urbanisation, population growth and human impacts of the industrial age. The pursuit of urban sustainability is thus one of several challenges of sustainable development (e.g. UN-Habitat, 2011; UN 2010).

Urban sustainability focuses on the human settlement as a multi-dimensional space, shaping and influencing sustainable development both locally and in the wider global context; a space that is manifested not just in the form of physical infrastructure, but also in terms of social, economic and environmental systems situated in settlements, as well as the administrative, institutional, political and cultural contexts influencing such systems (Arnott, 2012; UNHabitat, 2011). In recent years, efforts to combat climate change have taken an increasingly prominent role in discussions of urban sustainability, with energy and climate planning emerging as a central component of policy discussions at national and sub-national levels (European Commission, 2010; Lundqvist and Biel, 2007).

As the literature on urban sustainability increases in volume and diversity, so too does the need for interdisciplinary study of the theory and practice of urban sustainability. Urban sustainability is increasingly promoted as a concept by actors operating on the local, regional, national and international levels. However, there is no clear or unifying definition of sustainable urban development (Emilsson and Hjelm, 2009; West 2010). As such, interpretations of "urban sustainability" vary depending on context and other factors, and the concept may be considered by some to be a paradox, contradiction, oxymoron or chimera (Trisolini and Zasloff, 2009). 
Such debates provide a general context for this thesis, which - although it is unlikely to resolve differences in interpretation or other apparent challenges - attempts to make a contribution towards improving understanding of urban sustainability. To do so, the thesis deploys an exploratory approach. Experiences of strategic planning in municipalities, with specific focus on energy and climate planning, are presented in Papers 1-2, whereas Paper 3 reflects on recent academic literature to identify wider challenges related to the study and practice of urban sustainability. Were the thesis to focus on different themes, for example, water and sanitation or waste management, or a more specific sub-set of literature, it is possible that subtle, perhaps substantial, differences in results would emerge.

Notwithstanding that, the synthesis of results from these papers provides the basis for this thesis, which in turn proposes a conceptual framework - five factors for urban sustainability in municipal strategic planning - that aims to build on, complement and contribute to existing literature. In this regard, the thesis is less concerned with identifying gaps in past bodies of literature and framing research needs with reference to these, but rather more with identifying similarities and patterns across bodies of literature which - when synthesised into a coherent framework - contribute to the emergence of new insights and perspectives. Given the centrality of the municipality and municipal organisation to both the subject of this thesis, the appended Papers 1-2 and the topic area of urban sustainability, as addressed here and in Paper 3 , the thesis proceeds by clarifying what is meant by the municipality.

\subsection{Defining terms: municipalities, municipal organisations and stakeholders}

In recent years, the role of municipalities in enabling urban sustainability has been increasingly emphasised in a variety of academic and non-academic literature (e.g. ICLEI, 2012; Bulkeley and Betsill, 2007). However, as the term "municipality" may mean different things in different contexts, its use in this thesis will briefly be clarified.

Municipalities - territorial divisions with specific administrative functions, legal responsibilities and in many cases, political systems - often include, or are defined by their inclusion in, urban areas. The constitutional status of municipalities and their level of autonomy vary, depending on national legal and fiscal frameworks. In some countries, municipalities are considered synonymous with local government, although - as its name implies - the term "local government" may be understood to emphasise (political) government of the municipal space, and thereby omit the presence of other actors within (and outside of) the municipal territory that may also influence governance of the municipal territory (Rydin, 2010).

Both terms, local government and municipalities, imply the presence of an entity responsible for administration and in many cases, political management, of the municipal territory. Such entities are referred to in this thesis as municipal organisations. The institutional form of municipal organisations and their responsibilities, as well as the role of politics and extent of 
local democratic functions, is dependent on the national context. However, in many cases, the municipal organisation plays an influential role in municipal life by exercising authority or by influencing others (e.g. directly and indirectly through use of planning or in collaborative processes). The municipal organisation includes not only the institutions of local government, but also other actors, e.g. municipally-owned companies, and "governance" processes outside the scope of traditional "governmental" activities (Rydin, 2010).

The study of municipalities thus accommodates the study of other stakeholders (i.e. those with an interest in an issue) and municipal organisation's relationships with them (Zeemering, 2012). Generally, a stakeholder may be defined as an actor/entity affecting or affected by another's actions. The general public form an obvious group of stakeholders which may be organised and represented by political parties or other interest groups such as nongovernmental organisations, yet other stakeholders may include private companies, media, or other public authorities representing national or regional interests (Collins and Ison 2006; Polk and Knutsson 2008). The definition of stakeholder is loose and open to interpretation, with individuals and entities likely to consider others as stakeholders (or not) in different, sometimes inconsistent, ways.

\subsection{Framing the municipal context}

The literature studied in this thesis, together with the interpretations in the five municipalities which Papers 1 and 2 focus upon of whom or what are stakeholders and under which circumstances, employs no fixed or shared definition of stakeholder and should be interpreted as such. However, as this thesis emphasises governance, rather than government, of the municipal territory, it is understood that the municipal organisation is just one of many possible stakeholders operating within (and in some cases, outside of) the municipality. Stakeholders may have different goals or objectives, and may in some cases exert strong influence over municipal organisations (e.g. by shaping municipal perceptions about anticipated gains from investments).

Despite this, municipal organisations have significant legal, economic, political and social characteristics that provide them with important status, both within their own boundaries and outside (Rydin, 2010). In certain contexts, the municipal organisation may not be an important object of study, as it plays no role or exerts limited influence over an issue. However, on certain occasions, the municipal organisation may be assumed to be important, or have a "natural" role in a process, even though it may be inappropriate or detrimental to outputs or overall efficiency; and municipal inaction may give similar effects (Lindholm and Behrends, 2012).

Research can help illustrate the ways in which different contexts influence participation and performance. However, it may not always be possible or useful to make "like for like" comparisons between municipalities from different countries, nor the municipal organisations operating with them. Particular types of municipalities may be considered to share similar 
operating contexts, in the sense that they are entities located within agglomerations (e.g. Mexico City, London, Stockholm), whereas others may have one or more settlements of varying scales located within their geographic boundaries, which may in turn be located in close proximity, or far from, settlements in other municipalities (Rosenzweig et al, 2011a).

There may also be significant differences between municipalities - in terms of factors such as geographic size, topography, population, financing and resources, legal and political context and powers, etc. Comparative analysis of municipal organisations should always take into account such variation and be careful not to extrapolate or over-emphasise apparently significant findings (in terms of similarities and differences) too strongly (Rosenzweig et al, 2011b).

Similar challenges are evident when studying municipalities within a single national context. Although the formal role of municipalities is typically standardised (in a legal sense) and municipal organisations are instituted in a way that makes them a constant in an otherwise changing context (Smith and Wiek, 2012), there may be significant variation in the types of municipalities and the constellations of stakeholders operating within them (including the municipal organisation itself). The presence of differences, variations and similarities between and within municipalities may influence, for example, the ways municipalities act alone, in collaboration with others, or in competition. Thus, municipalities are a diverse group, of which some municipalities share similar characteristics, albeit for many different reasons. Discussing "rural sustainability" may be more relevant than "urban sustainability" in some municipalities; similarly, some municipalities may consider the "urban unsustainability" of others as a greater concern than their own "unsustainabilities" (Seitzinger et al, 2012).

\subsection{Focusing on the Swedish context}

The focus on municipalities thus runs the risk of approaching urban sustainability in terms of one-size fits all "solutions" that neglect the diverse contexts in which municipalities operate. Municipalities exist within wider contexts, in terms of the nation states in which they are located, as well as other sub-national or supra-national entities that influence their operating contexts, and the international system in which national governments liaise. For example, the European Union has been keen to encourage subsidiarity with regard to urban sustainability that is, to promote devolution of powers and thus emphasise the role of municipalities perhaps as a means of stimulating progress on sustainable development in the face of deadlock in intergovernmental negotiations (Minoia et al, 2009).

Irrespective of whether this actually occurs, there remains considerable diversity in terms of the municipalities operating within the European Union. According to the Council of European Municipalities and Regions, in 2007 there were 92,506 sub-national governments in the EU, of which 91,252 were classified as municipalities. Almost 37,000 of these were in France, compared to only 450 in the United Kingdom. The average European municipality had a population of 5,410 inhabitants residing in an area of approximately $50 \mathrm{~km}^{2}$ (CEMR, 
2009). This tends to lend some credence to the aforementioned point concerning "rural sustainability" - it is not automatic that a municipality has a large population or is necessarily urban.

This point is illustrated by the municipalities studied in Papers 1 and 2 of this thesis, which are located in Sweden. In 2011, the median Swedish municipality had a population of approximately 15,000 inhabitants (SALAR, 2012; giving an average population of around 33,000). Thus, in European terms, four of the five municipalities studied in Papers 1 and 2 municipalities may be considered "above average" in size, with only the smallest being "average". That said, in terms of urban populations, Swedish municipalities are - in global terms - almost exclusively small-medium-sized conurbations, i.e. having populations of less than 500,000 .

UN-HABITAT suggests that by 2020, approximately half of the world urban population - and $60-72 \%$ of Europe's population - will live in communities of this size. In other words, smaller urban agglomerations will house over 2 billion people globally, of which around 370 million will reside in the EU (UN-HABITAT 2011). Thus, small-medium-sized conurbations are likely to play pivotal and multiple roles in the process of urbanisation, as regional hubs, as recipients of rural-urban migration, and as embedded infrastructure. Experiences from Swedish municipalities may thus be interesting to consider, both within the European context and in a wider perspective. However, Swedish municipalities operate within a somewhat unique context.

Wollmann (2008) states that the "principle and practice of local self-government is rooted in Sweden's history more deeply and endurably than in any other European country" (p. 259) and that the "long-standing taxation powers of local government is a key feature of Swedish local government (unique among contemporary local government systems)" (p. 282). Swedish municipalities are empowered with a clear constitutional mandate, significant legal powers including a planning monopoly - as well as fiscal rights. Nevertheless, legal rights and financial resources also incur responsibilities, and municipal portfolios are diverse, including roles ranging from provision of infrastructure to distribution of welfare, education, and more. Moreover, there is enormous diversity within the category "municipalities", in terms of e.g. geographic, economic, environmental and social conditions (see e.g. Fredriksson, 2011; SALAR, 2009).

This diversity is illustrated, and explored in more detail, in the experiences of five municipalities in Papers 1 and 2. These papers focus on a task which municipalities are legally obliged to fulfil - energy planning - that has, in recent years, been increasingly linked with efforts to combat climate change. Energy and climate planning is thus a strategic task of Swedish municipalities, one which the Swedish Energy Agency has attempted to support by initiating the Sustainable Municipality programme (which financed the studies on which Papers 1-2 are based) (Swedish Energy Agency, 2011). 
The Sustainable Municipality programme aims to support municipalities in developing sustainable energy systems through knowledge diffusion, provision of networking support and with financial support to coordination projects within and between municipalities. Municipalities applied to join the programme, meaning participants demonstrated a basic willingness to address the issues of sustainable energy and climate change. 66 municipalities participated in Phase II of the programme during the period 2008-2011, which strongly focused on the development of energy and climate strategies (Swedish Energy Agency, 2011).

The presence of a legal mandate, as well as institutional support at the national level, mean the Swedish context is somewhat different to others, in which municipal organisations may be subject to major barriers or impediments. Thus, whilst experiences from Swedish municipalities may be interesting to consider, one should remain cautious when drawing conclusions about the relevance of such information to other contexts.

\subsection{Urban sustainability and the municipality}

There are a variety of ways to frame research on municipalities and urban sustainability and numerous challenges related to the study of both. The framing of sustainable development as a challenge requiring subsidiarity and local-level responses has led to strong emphasis - both from policy-makers and scholars - on the role of municipalities in sustainable urban development. Often, literature on urban sustainability focuses on the role of municipalities in shaping local, context-specific transitions, which may have broader significance to municipalities operating in similar contexts (Rydin 2010; Droege, 2008). The municipality (i.e. its geographic zone) is a platform for study; within it, the municipal organisation (i.e. the municipal entity) is an object of study, although not necessarily the sole or major object of study as in a study of local government (Aguilar and Santos, 2011).

However, it is unclear if, how and to what extent municipalities have been able to make progress, either because regulatory contexts have not enabled them to do so, because of local factors such as regulatory powers, or because of perceptions leading to loss averse behaviour (e.g. Trisolini and Zasloff, 2009; Kahneman and Tversky, 1979). The municipality itself may contain more than the urban space, or may be part of (and inseparable from) wider urban, regional, national or global contexts. Thus, whilst the geographic boundary of the municipality may represent an obvious tool in defining and limiting the scope of studies, it is unclear to what extent it should be the decisive factor; the municipal boundary imposes a striated physical space, that is anthropogenic and intertwined with power and politics (Deleuze and Guattari, 2003).

Nonetheless, the constant position of the municipality in municipal life and its centrality - as an object of study, or the context of study - to studies on urban sustainability means that it is hard to imagine otherwise. Municipal organisations and processes in which they are involved thus become an important reference point and often the focus of studies, despite uncertainty that municipalities have the organisation, processes or tools to adequately address 
sustainability concerns in a strategic manner (Farreny et al, 2011; Zeemering, 2012). As such, a reconceptualisation of the municipal organisation's role may be necessary to improve sustainability performance (Mori and Christodoulou, 2012; Cook and Swyngedouw, 2012).

Moreover, although urban sustainability is a phenomenon that seems inextricably linked to municipalities and municipal organisations, it - by virtue of its complexity and diversity affects and is affected by stakeholders, both locally and outside of the municipal zone (Seto et al, 2012; Seitzinger et al, 2012). The interconnected dynamics of urban sustainability make it unlikely that any actor working in isolation can adequately address challenges of urban sustainability in a holistic way (see e.g. Newell et al, 2012). As such, it may be interesting to consider how other actors participate in initiatives aiming for urban sustainability, either within or outside the framework for processes initiated, organised by or involving the municipal organisation. Such actors may include those defined conventionally as stakeholders (i.e. those with a clearly-defined or direct interest in an issue) to other constellations of actors or individuals who are absent from, or on the fringes of, formal processes (Porter, 2011).

In sum, studies on the role of municipalities in urban sustainability face a number of challenges, in part related to the underlying complexity of sustainable development, urban sustainability and the ways in which information on these issues are structured, organised and presented, and in part the consequence of the diversity of municipalities, both as a category and internally, within and between municipalities and the wider contexts shaping municipal contexts. Despite this, municipalities - as defined geographic zones - are ideal units of study, housing enormous diversity and extensive potential empirical material for studies. The municipal unit is attractive to academics, both in practical terms and intuitively. Associating the municipality with urban sustainability is perhaps a heuristic, one that, even if somewhat problematic, is not without merit or logic.

In other words, scholars should make some attempt to consider how studies of urban sustainability in municipalities are constrained by the study of both urban sustainability and municipalities; and the extent to which any issues studied may be said to be specific to or arise from particular municipal contexts, as unique manifestations of phenomena in a specific location may distort understanding of underlying characteristics shared by other municipalities. Scholars attempt to resolve such challenges in various ways, e.g. by placing municipal examples in the wider context of sustainability, or by relating their findings to other kinds of concepts or categories. For example, studies may focus on general characteristics or specific themes (see e.g. Hollander et al, 2012) and often make use of single or multiple case studies, or comparative data sets. The impacts of such approaches are explored in the appended Paper 3, with multiple comparative case studies being a central tool of analysis in the appended Papers 1-2. 


\subsection{Focusing on strategic planning}

This thesis reflects upon some of the issues related to urban sustainability in municipalities outlined above by looking in greater detail at the question of municipal strategic planning, and with particular reference to energy and climate strategies. There are good theoretical grounds for doing so. Strategic planning is an issue of concern for most organisations and recent research on corporate strategy suggests that environmental issues and sustainable development are increasingly influencing strategic planning processes (see e.g. Sandhu, 2010; Porter and Reinhardt, 2007). Sandhu (2010, p. 302) identifies a need for "businesses to move beyond regulatory compliance and toward adopting a strategic proactive approach" that recognises the profound, long-term implications of sustainability challenges. This is important because there is often a normative "alignment of an organization's activities with its strategies" (Thornley, 2012, p. 374).

Thus, as Thornley (ibid) says, "one of the greatest threats to sustainability in any form is the failure of organizational strategies, policies and initiatives to translate into actual project execution and work results that are consistent with those ideals". Short-termism, lack of will or resources, and organisational complexity - as well as myopic tendencies - may be among the factors that lead to poor strategies or performance on sustainability issues (Johnson and Macy, 2001). Nevertheless, much of the literature on strategic planning focuses on examples from the private sector. Rashman et al (2009) advocate a wider scope for organisational studies, to better account for the public sector and others involved in strategic planning. Of course, analytical frameworks developed primarily with private sector organisations in mind should not be used unquestioningly or without reservation (Pettigrew et al. 1992, p. 5; cited in Rashman et al, 2009). Nevertheless, the use of such frameworks may help demonstrate their utility, illuminate points of debate and thus contribute towards the development of "a broader range of conceptual approaches to organizational learning and knowledge" (Rashman et al, 2009, p. 487).

\subsection{Strategic planning in municipalities}

The application of analytical frameworks aimed at private sector organisations may, for example, enable a contribution to theoretical development on urban sustainability governance, a field in which recent literature suggests that municipalities need to "think beyond city limits" to expand the scope of their processes and increase their interactions with stakeholders in participatory process (e.g. Seitzinger et al 2012; Williams, 2010; Nyseth, 2008). In addition, widening the scope of organisation studies seems highly relevant to many national contexts where, following long periods of new public management reforms, the role of public sector organisations has been transformed (Smith and Wiek, 2012; Watson, 2003; Wellstead and Stedman, 2011).

Swedish municipalities, for example, have imported organisational models and management techniques, as well as personnel, from the private sector; municipal companies have been 
privatised or hived off; and the role of external stakeholders in municipal operations has increased through e.g. sub-contracting or new partnership models (Fredriksson, 2011). At the same time, the complexity and urgency of the sustainable development paradigm has become increasingly clear and the multi-faceted, dynamic and "glocal" challenges of urban sustainability has emerged as a topic of major interest to public and private sector actors alike (Acuto, 2013; Gupta et al, 2007; Levidow and Oreszczyn, 2012).

Moreover, as many studies have shown, municipalities play a central role in developing, implementing and guiding strategic visions of urban sustainability (see e.g. Gustafsson and Hjelm, 2011; Emilsson and Hjelm, 2009). This thesis focuses on the ways in which municipalities develop strategic planning for urban sustainability, with specific reference to energy and climate strategies. In this context, strategic planning does not mean urban planning, but rather refers to municipal strategies and policies that shape and influence the overall operation of the municipal organisation, including municipally-owned companies, as well as wider developments within the municipal territory.

The processes used to develop such strategies may or may not include external stakeholders, enabling the research to explore the implications of adopting participatory approaches on both the process and the outputs of a process. Many researchers in the field of organisation studies consider stakeholder participation as desirable in strategic planning processes. For example, Polonsky et al (2011) cite Porter and Reinhardt (2007) to note the value of involving stakeholders in development of regulatory frameworks for climate change. Participation is considered to enhance the impact of strategies, contributing to the catalysing effect of the need to outperform rivals (see e.g. Jukic et al, 2011; Valentine, 2010).

Thus, by addressing the municipal organisation - a public sector body - and the involvement of stakeholders in municipal strategic planning, the thesis avoids the "over-reliance on the private sector as the principal source of theoretical understanding and empirical research" in existing literature (Rashman et al, 2009, p. 463). As such, the thesis will make both a direct contribution to the study of strategic planning for urban sustainability in municipalities, and a wider indirect contribution to the field of organisation studies. 


\section{Methodology}

In this section, the research methodology used to gather and interpret materials will be presented and discussed.

\subsection{Research design}

The Research Questions (RQs) were framed to enable reflection on both the practice of urban sustainability in situ and the practice of researching urban sustainability. Research Questions 1 and 2 focus on the issues of how urban sustainability is integrated into municipal strategic planning processes; which organisational forms, methods, tools, concepts and approaches are utilised; and who is involved in such processes. Papers 1-2 make use of empirical material from the "Sustainable Energy and Climate Strategies" research project (HEKSA) to respond to RQ1 and RQ2. The papers specifically concern findings from the HEKSA project and make use of mixed qualitative methods (see Table 1).

In contrast, Paper 3 responds to RQ 3 and reviews a selection of recent scientific journal articles, identifying trends and topics of importance in discussions of urban sustainability. Together, the three papers enable reflection on the state of urban sustainability practice and research, and form the basis for the Synthesis discussion of this thesis. The links between the three papers is illustrated in Figure 1 - the illustration depicts two circles that are not mutually exclusive, but rather are interactive and mutually reinforcing, enabling different perspectives to be illuminated.
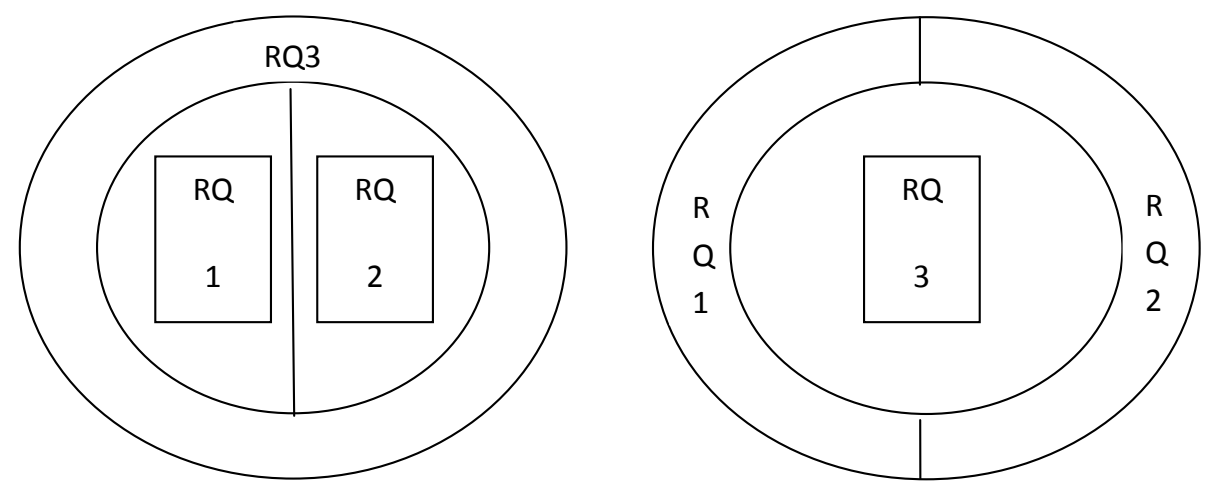

Figure 1. The interaction between the Research Questions / Papers. On the left, the case studies responding to RQ1 and RQ2 provide the central focus of the thesis, with the review paper (responding to RQ3) providing the context or theoretical framework that supports analysis; on the right, the debates illustrated by RQ3 are central, yet complemented and contrasted by empirical findings from RQ1 and RQ2. The two illustrations are not mutually exclusive and this thesis builds upon analysis conducted using both approaches. 


\subsection{Research methods}

As Table 1 shows, a variety of qualitative research methods were used to conduct the research. Whereas quantitative research methods emphasise data and often search for probabilistic correlations or relationships in numerical form, qualitative research methods are commonly used to explore the development of meanings, concepts or characteristics (Berg, 2009). As such, qualitative research is less focused on supplying answers than in understanding phenomena and evaluating the impact of social processes on such phenomena, which in turn influences both the framing of the questions and answers scrutinised in quantitative studies. Mixed method studies combine aspects of both these approaches (see e.g. Creswell, 2008; Flick, 2009; Goertz and Mahoney, 2006; King, Keohane and Verba, 1994; Miles and Huberman, 1984).

Qualitative research may have different goals, ranging from theory generation (e.g. Eisenhardt and Graebner, 2007; Golden-Biddle and Locke, 1993); to theory elaboration and theory testing (see Lee et al, 1999). The combination of methods used in qualitative research thus depends partly on the aims of the researchers and partly on the context to be observed.

Table 1. Overview of methods used for each Paper. Note that the sequence in the Table broadly corresponds to the steps taken when preparing Papers 1 and 2. Paper 3 was developed independently of (and after) the other papers.

\begin{tabular}{|l|l|l|}
\hline Method & Paper(s) & Explanation \\
\hline Survey & 1,2 & $\begin{array}{l}\text { Sent to 66 municipalities; 60 responses. } \\
\text { Quantitative and qualitative analysis of responses. } \\
\text { The survey responses informed case selection. }\end{array}$ \\
\hline $\begin{array}{l}\text { Phone interviews (prior } \\
\text { to case selection) }\end{array}$ & 1,2 & $\begin{array}{l}\text { With individuals in 10 municipalities; informed } \\
\text { case selection of 5 municipalities. }\end{array}$ \\
\hline Group interviews & 1,2 & $\begin{array}{l}5 \text { group interviews, 1 per municipality - average } \\
4.8 \text { participants per group interview (and 2.4 } \\
\text { researchers) }\end{array}$ \\
\hline Document study & $1,2,3$ & $\begin{array}{l}1,2 \text { - total 125 documents (5 municipalities) and } \\
\text { literature reviews (strategic planning; stakeholder } \\
\text { participation) }\end{array}$ \\
\hline Individual interviews & 1,2 & $\begin{array}{l}3-\text { literature review: sample of 82 full articles } \\
\text { from 122 publications during 2011-2012. }\end{array}$ \\
\hline Observations & 1,2 & $\begin{array}{l}10 \text { individual interviews } \\
\text { Documented by researchers }\end{array}$ \\
\hline Single case study & 1,2 & $\begin{array}{l}\text { One per five municipalities in which results from } \\
\text { the document study, survey, and interviews were } \\
\text { documented }\end{array}$ \\
\hline $\begin{array}{l}\text { Multiple case studies - } \\
\text { comparative analysis }\end{array}$ & 1,2 & $\begin{array}{l}\text { Comparative analysis of the five case studies } \\
\text { analysing from different perspectives, e.g. } \\
\text { strategic planning and stakeholder perspectives }\end{array}$ \\
\hline Overall description & & $\begin{array}{l}1,2 \text { - Mixed qualitative } \\
3-\text { Review paper }\end{array}$ \\
\hline
\end{tabular}




\subsection{Papers 1-2}

This thesis presents findings from two papers including extensive case study research, responding to RQ1 and RQ2 respectively. Both Paper 1 and Paper 2 concern findings from the HEKSA project, which studied the ways in which municipalities participating in Phase II of the Swedish Energy Agency's "Sustainable Municipality" programme prepared energy and climate strategies. Research addressed issues including the availability of support tools in the form of handbooks and the extent to which municipalities used them; participation and the ways in which stakeholders were involved in developing strategies; and the organisation of processes to develop strategies.

The author joined the project in September 2011 and worked on it until the project ended in December 2012. During this period, he participated in each of the Methods presented in Table 1 except the Survey (which was concluded prior to him joining the project) and the Phone Interviews (which were conducted by Sara Gustafsson and Jenny Ivner).

The case studies were compiled using a mix of qualitative methods. The methods used include document studies, a survey, phone interviews, group interviews, individual interviews, and observations. These methods are frequently used in case study research (e.g. Gerring, 2008; Thies, 2002; Rubin and Rubin, 2011) and are discussed in more detail in the appended papers. A brief summary is provided here and in Table 1.

For each of the five municipalities, a document study of publicly-available documents related to the municipality's work with energy and climate strategies or overall strategic planning was conducted. All documents that the researchers could access using the internet were studied and used to develop data sheets and timelines for the municipalities. Interview questions were developed with reference to the themes identified when comparing this information.

Semi-structured individual and group interviews were held in each municipality and used for all case studies, enabling the researchers to clarify and ask follow-up questions. Interviews were transcribed. One case study per municipality was prepared, describing the findings from the aforementioned activities. These case studies were then studied in a comparative format, with particular reference to the themes of strategic planning and stakeholder participation. The decision to write two papers addressing different theoretical perspectives reflects the large quantity of empirical material available to the authors and the relevance of this material to the respective topics of strategic planning and stakeholder participation.

\subsubsection{Comments on the methods used}

The methods aimed to provide a comprehensive framework for developing the case studies upon which Papers 1 and 2 are based. Table 1 provides an overview of the methods and brief explanations concerning the activities and purpose of different actions. The Papers also include literature reviews addressing strategic planning (Paper 1) and stakeholder participation (Paper 2). The literature reviews are based on the shared knowledge of the 
authors and aim to synthesise the theoretical backgrounds of the topics of focus. No particular method was used to conduct these reviews.

There are obviously some advantages and disadvantages with different research methods. In the case of these studies, there was a clear sample, i.e. participants in the Sustainable Municipality programme, and a good response rate to the survey. The selection of cases for detailed study was made based upon responses to the survey, subsequent telephone interviews with ten selected municipalities, and a combination of other criteria, e.g. a desire to represent different municipalities in terms of size, geographical location, background, etc. There is thus a risk that the attempts of the researchers to ensure a representative sample may in turn have skewed the sample towards: (a) respondents, (b) respondents whose answers prompted follow-up discussions in telephone interviews, and of these, (c) municipalities with different contextual circumstances.

Similarly, the document study used to compile information about the five municipalities was limited to publicly-available documents gathered from the municipalities' websites and those of related actors (e.g. Sustainable Municipality). Information pertinent to the content of the case studies may have been missed, despite the researchers' efforts not to do so. Similarly, the composition of group interviews was influenced variously by available information, selection by the contact person in the municipal organisation, the availability of participants, and suggestions by group interviewees.

The Coordinators of energy and climate planning processes in each municipality invited participants they considered to have been active during the process to group interviews, and many were able to attend. Some unable to attend were reached by telephone, but it is possible that some potential participants unable to attend or not informed about the interviews were not contacted. For this reason, at each group interview, the researchers asked all attendees for the names of participants that could be interviewed, and several such follow-up interviews were conducted. However, there is risk that interviewees represented "insiders" or excluded other stakeholders (although it should be reiterated that the focus of the studies was on the process and participation in the process). The inclusion of other or more interviewees may have produced some different results or interpretations.

Finally, in qualitative studies - and particular in case study research - much depends on the ability of the researchers to accurately record and interpret information. The interdisciplinary character of the research team, together with careful and deliberate measures to reinvestigate and reinterpret material on repeated occasions, should mitigate against such errors or misinterpretations. 


\subsection{Paper 3}

Paper 3 presents findings from a review of recent scientific journal articles on urban sustainability. Literature reviews often provide a means of understanding the state of research in a field and, in doing so, provide guidance and support in framing possible research questions (Boote and Beile, 2005; Creswell, 2008; Webster and Watson, 2002). Literature reviews should be systematic, reproducible and as comprehensive as possible (Fink, 2005).

The approach used for Paper 3 was inspired by recent review articles (e.g. Brandt et al, 2013; Cook and Bakker, 2012; Rashman et al, 2009). The adapted systematic review methodology comprises four steps - identification of sample (Step 1); selection of sample (Step 2); categorisation (Step 3); and analysis (Step 4) - to offer a conceptual synthesis of the content and identify areas warranting further attention (Rashman et al, 2009). These steps are fully described in Paper 3.

Paper 3 aimed to assess the state of the art in urban sustainability research, in order to improve understanding of how urban sustainability is framed in academic studies. In particular, the study attempted to identify themes and trends worthy of attention or consideration in future studies. In this thesis, these findings are related to the results of Papers 1 and 2 in order to develop a conceptual framework for studying urban sustainability in municipalities.

Paper 3 is based on comprehensive analysis of a sample of 82 articles published during the period 2011-2012 and selected from a wider sample of 338 related publications identified using the term "urban sustainability" in the abstract, title or keywords and listed in the Scopus Social Sciences \& Humanities database (in total there were 122 incomplete records for 20112012). As such, the sample is limited and should be understood as indicative rather than fully representative of all urban sustainability literature.

The analysis in Paper 3 could possibly be extended in future analysis. However, in its current form, the findings represent the author's interpretation of the content of a selection of recent scientific journal articles, rather than a definitive study. Clearly, as a review paper based on the author's interpretation of other scholars' work, there is an element of subjectivity concerning the analysis and conclusions contained in Paper 3. The author has attempted to mitigate against such risk by clearly describing the methods used to conduct the analysis.

\subsection{Writing the Thesis}

The results of this thesis depend upon the way that it was prepared; a short description of this process follows.

The author reflected on the findings of Papers 1-3 individually and collectively, in order to identify commonalities between the three papers. Noteworthy themes or issues, and their implications, were explored in each paper; these findings were reconsidered and reinterpreted 
with respect to the findings of the other papers. This analysis helped the author identify the five factors as common and recurring issues of importance which are synthesised into the conceptual framework presented in the Synthesis Discussion.

It should be noted that, when drafting the thesis, the author attempted to present the information in different ways. First, the thesis had its theoretical base in the history of urbanism and the more recent emergence of urban sustainability in this context. The current Paper 3 provided a natural "umbrella" for reflection upon the state of the art in urban sustainability debates, with Papers 1-2 focusing in more detail on the Swedish context, energy and climate planning, and the themes of organisation and participation. In a subsequent revision, the author attempted to reframe these discussions with emphasis on the experiences highlighted in Papers 1-2 and the relevance of these to wider discussions on urban sustainability, as illustrated by Paper 3 (this perspective also corresponds to the chronology of the studies).

In other words, the early versions of this thesis emphasised the results in a historical perspective, whereas the subsequent versions have emphasised the historicism of results and are more deeply grounded in the empirical material. The philosophical implications of viewing material in different ways are perhaps best explored by others (e.g. Grumley, 1989). Nevertheless, the conceptual framework emerging from this thesis emerged from both perspectives (as Figure 1 attempts to illustrate) and remains relevant to both perspectives. In this way, the Synthesis Discussion - as well as the five factors proposed - represents the outcome of a deeper process of exploration, reflection, interpretation and reinterpretation than may appear obvious. Some of the limitations of this process will be explored in the following section.

\subsection{Limitations and reflections on choice of methods}

This thesis cannot and does not claim to provide a comprehensive assessment of all aspects of the urban sustainability debate, if indeed this were possible. As such, the thesis primarily addresses issues concerning governance and participation, or management and organisational form, rather than say, architecture, urban development projects or investment programmes.

General constraints concerning the study of urban sustainability have been discussed in the Introduction and Theoretical background. Each study has limitations, which are addressed in the respective Papers. A further limitation is practical and concerns the time available for studies and the limitations of research projects and funding, which determined the extent and type of empirical material available to the researcher. Whilst it is often desirable to pursue deeper, wider or more comprehensive studies, it is not always feasible to do so.

Papers 1 and 2 present information in article form, with corresponding restrictions on length and content. Whilst this provides some degree of focus, it also limits the amount of information that is possible to include. A more comprehensive account of the studies is thus 
provided in Fenton et al (2012). In addition, both papers are based upon empirical data from the same research project, and particularly focus on different findings from five municipalities, narrowing the scope of the research.

In contrast to Papers 1 and 2, Paper 3 and this thesis are the work of the author, rather than a team of researchers. As such, the analysis contained within both is dependent upon the author's interpretational skills. It is hoped that the methods described above go some way towards mitigating against any possible errors or misinterpretations. 


\section{Presentation of papers}

\subsection{My contribution}

In the following section, brief information on each of the three papers is presented. The author has contributed to these papers in the following ways:

Papers 1 and 2: The author joined the research project after the survey but prior to data collection for the case studies. The case study research was collaborative and involved the four researchers. The author was the lead author for both papers, with Sara Gustafsson and Jenny Palm providing the main support in terms of theoretical input, comments, etc.

Paper 3: the review was designed, undertaken and written by the author. Comments on the structure and presentation of the paper have been provided by Sara Gustafsson and Olof Hjelm.

\subsubsection{Paper 1 - Sustainable energy and climate strategies: lessons from planning processes in five Swedish municipalities}

Paper 1 makes a contribution to understanding Research Question 1 - How are processes to develop energy and climate strategies organised in Swedish municipalities?

The study considers the ways in which five municipalities participating in the Sustainable Municipality programme organised the processes to develop their energy and climate strategies. The paper analyses the impact that different organisational choices had on the scope and contents of strategies.

The study found that municipalities that actively enabled stakeholder participation during the processes to develop energy and climate strategies were able to develop strategies that were wider in scope, whereas municipalities that limited stakeholder participation were able to address fewer issues with a more limited scope. These results are explained with reference to proposed communicative or rational models of governance and government.

Findings from this study were presented at the Greening of Industry Network Conference in Linköping, 22-24 October 2012. The paper has been submitted to a special edition of the Journal of Cleaner Production (decision pending).

\subsubsection{Paper 2 - Stakeholder participation in municipal energy and climate planning - experiences from Sweden}

Paper 2 makes a contribution to understanding Research Question 2 - How do stakeholders participate in energy and climate planning in Swedish municipalities? 
The paper analyses the factors influencing stakeholder participation in municipal energy and climate planning, together with stakeholder experiences of participation in such processes. Results from a survey of 60 municipalities are presented, together with detailed case studies analysing stakeholder experiences from involvement in energy and climate planning in five municipalities.

Results suggest that issues such as the level of political engagement and ways that planning processes are organised impact upon stakeholder perceptions of a process and the extent to which outputs are viewed in positive or negative terms. The results complement the findings of RQ1 and contribute to literature on governance, networks and participation.

Preliminary findings from the study were presented at the $3^{\text {rd }}$ International Urban Research Symposium (ICLEI World Congress, 13-18 June 2012, Belo Horizonte, Brazil). The paper has been submitted to Local Environment (decision pending).

\subsubsection{Paper 3 - Exploring the state of the art in urban sustainability literature - what do recent articles reveal?}

Paper 3 responds to Research Question 3 - What do recent scientific journal articles on urban sustainability reveal about the study and practice of urban sustainability?

82 recent scientific journal articles addressing the theme of urban sustainability were reviewed to assess factors such as the availability and type of literature, the methods and tools used in the literature, themes or topics covered in the literature, and the ways in which future research could contribute to current literature. The review provides a framework for study by identifying patterns in urban sustainability practice and research and by identifying key issues to be addressed by future research.

The results indicate a number of challenges for scholars and practitioners when designing or implementing projects aiming to contribute to or assess urban sustainability, not least with regard to governance, participation, and normative tendencies that influence the framing of policies, practice and studies.

The review was presented at the $3^{\text {rd }}$ International Interdisciplinary Ph.D. Workshop in Sustainable Development on 12-13 April 2013 at Columbia University, New York, USA. The paper has been submitted to Local Environment (decision pending). 


\section{Results}

Results from the three papers are explored in the text below and form the basis for the "five factor" concept introduced by this thesis. This concept will be explored in more detail in the subsequent Synthesis discussion.

\subsection{Papers 1-2}

Papers 1-2 make specific contributions to the study of municipal energy and climate strategy planning processes in Sweden and general contributions to discussion on organisational theory and participation. Papers 1-2 illustrate the ways in which Swedish municipalities participating in the Sustainable Municipality programme organised the processes to develop their energy and climate strategies, the methods used and the extent to which stakeholders participated in such processes.

In particular, the papers illustrate experiences from five municipalities which (with reference to the Swedish context) were categorised as small, medium and large municipalities, but in an international perspective would be described as small-medium-sized municipalities (with emphasis on small). An overview of the five municipalities is provided in Table 2; for further information, refer to Papers 1-2 or Fenton et al, 2012.

Results suggest that a number of factors influence the development of municipal climate and energy strategies and their content. Influential factors include the importance of a clear, shared vision and engaged politicians; the size and organisational structure of the municipality and its willingness and capability to act; the organisation of the process and extent to which stakeholders not only have been involved but also felt included; the need for clarity about financial aspects, such as planned financing of implementation; and the need for greater clarity concerning selection of targets and their relevance to global climate and energy trends.

The results were used to propose basic models for interpreting differences in approach between municipalities. The research found that differences do not necessarily arise because of contextual factors such as the relative size or resources of a municipality, but rather by the extent to which municipalities select rational or communicative approaches during strategic planning, which in turn determines e.g. the way resources are allocated during and after processes. As Table 3 shows, rational approaches imply a more traditional "government" approach to strategic processes, whereas communicative approaches relate to "governance" in strategic processes. 


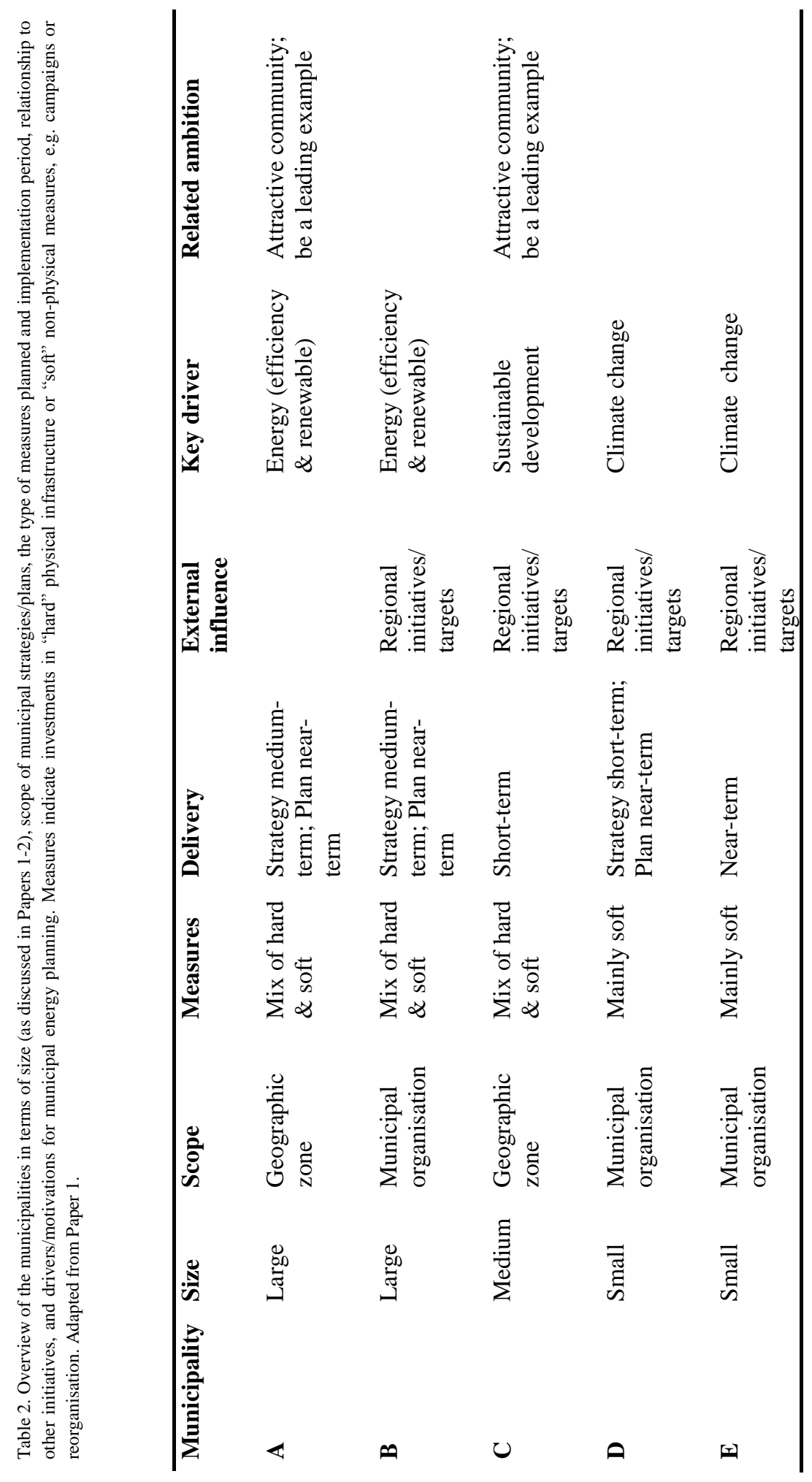


Table 3. Different characteristics associated with the rational and communicative models in strategic planning processes (a mix of characteristics may be observed). Illustration inspired by various sources, e.g. Khakee, 2000; Campbell and Fainstein, 2003; Albrechts, 2004; Healey, 2009; Fredriksson, 2011. (Adapted from Paper 1).

\begin{tabular}{|l|l|}
\hline Rational & Communicative \\
\hline Linear & Non-linear \\
\hline Top-down & Bottom-up \\
\hline Exclusive & Inclusive \\
\hline Regulatory & Voluntary \\
\hline Formal & Informal \\
\hline Government & Governance \\
\hline Division between politicians and planners & Participants \\
\hline Narrow scope (municipal organisation) & Wider scope (geographic zone) \\
\hline
\end{tabular}

The tendencies noted in Table 3 should only be interpreted as being indicative and in no way deterministic; a mix of characteristics may be observed in some contexts. As noted above, the selection of approach may depend on a variety of factors, i.e. the way that capacity, mandate, resources and will (of politicians to act, of stakeholders to participate, etc) influence perceptions about the scope for action and of action. This issue is explored in Paper 1 with reference to the rational and communicative models, and further developed in Paper 2.

As Paper 2 makes clear, scope is perceived in terms of direct control/influence in a rational model, whereas a wider range of externalities are accounted for by the communicative model. This is illustrated in Figure 2. Actors choosing to focus only on issues they directly control are employing the rational model and perceive their influence in limited, restricted terms. Moving away from the centre, actors may choose to include issues they indirectly control in the scope of processes, or consider how they employ "soft power" to exert indirect influence over others to achieve wider effects.

This means that the transition from rational models focusing primarily on direct control, to communicative models, which attempt to provide a more holistic approach, necessarily widens an actor's conceptualisation and interpretation of the scope of their 
influence (see Figure 2). This also increases the range of issues to be considered during the process, the number of stakeholders to be involved, etc.

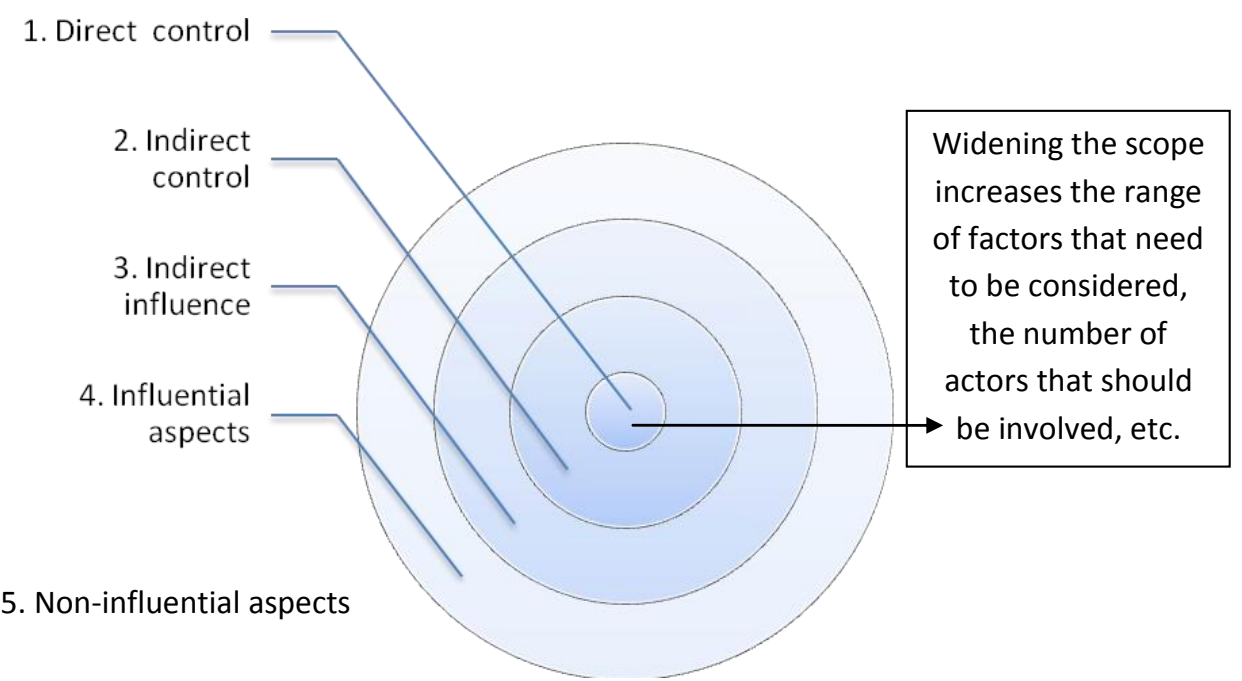

Figure 2. Different types of scope from Direct control to non-influential aspects. (As presented in Paper 2).

As processes become more communicative, they are more likely to extend in scope and, from the actor's perspective, lead to increased awareness of not only how "we" (the municipal organisation) influence others, but also how others influence "us". This is achieved by considering influential aspects, and results in the transformation of the actor from an initiator or owner of a process to a participant in a process. Moreover, increasing awareness of influential factors is linked to awareness of non-influential factors, which may not be directly relevant in the particular context, yet may inform the other scopes and be difficult to perceive when employing a rational approach. As Paper 2 suggests, these findings illustrate the importance of systems thinking (Senge et al, 2005).

By developing the rational and communicative models and elaborating on the impact of scope, Papers 1-2 contribute to understanding how the general characteristics of strategy planning processes (in terms of organisation, participation, capacity, and resources) interact with political and legal dynamics (e.g. scope, will and mandate). This interaction shapes the overall form and content of processes, and differences between municipalities are considered to stem from differences in the use of rational or communicative approaches. 
Papers 1-2 were unable to assess the extent to which the outputs of such processes - the strategies - are implemented in part or full, yet the relative success of implementation is likely to depend upon such factors and to vary both within and between contexts. In both phases (planning and implementation), the relationship between the local targets and global challenges is critical to any attempt at normative judgements concerning the "sustainability" of the strategies.

\subsection{Paper 3}

In contrast to Papers 1-2, which make specific contributions to the study of municipal energy and climate strategy planning processes in Sweden and general contributions to discussion on organisational theory and participation, Paper 3 assesses a sample of recent scientific journal articles and encourages reflection in broader debates on urban sustainability.

The 82 articles assessed in Paper 3 make use of different approaches and address a diverse range of themes with reference to urban sustainability. The 82 articles present information that is both general and specific, ranging from case studies and datasets to theoretical discussions or reviews.

The articles emphasise the importance of the concept of urban sustainability and its relationship with other phenomena, whilst underlining the difficulty of defining the concept or determining how to measure or monitor performance. Recurring challenges include the need to factor in up- and downstream impacts or linkages when preparing strategies or evaluating outcomes; the need for inclusive participatory processes; and the challenge of distinguishing between context-specific and generalisable factors and research findings.

A number of issues are noted in the literature but discussed in less detail than the aforementioned points. These include political dynamics - namely the intertwined issues of scope, will, and mandate. Scope provides the legal, institutional, constitutional and organisational basis for action - the opportunity to act; will is the desire to act; and mandate gives politicians the right to act in a manner that will be perceived as legitimate. The literature touches upon these points, without substantially addressing how to address or secure them, individually or collectively. Similarly, issues such as capacity and resources are raised by the scientific journal articles, albeit mainly in an indirect or incomplete manner.

In sum, the literature review shows that - among other things - there is a need for detailed study of urban sustainability governance, including the study of organisational aspects, processes, and levels of participation. There is a need to consider how issues are framed and impact on scope, will and mandate, if urban sustainability is to 
overcome factors that lead to short-termism, inertia or inaction. Such studies should focus not only on - or from the perspective of - municipalities and municipal politicians, but also on other stakeholders and with an awareness and sensitivity towards "invisible" interest groups, both locally and in other geographic locations.

Paper 3 also reveals that approximately two thirds of recent articles present casespecific information about municipalities, with the majority of these focusing on single national contexts. The widespread use of case studies to "frame" urban sustainability studies risks generating imbalances in the literature, for example through ethnocentric focus on particular countries or cities; technocentric focus on specific themes or topics; focus on highly formalised institutions, processes and mechanism; data or indicators; or specific "categories" of urban form or actor, e.g. megacities or municipal organisations.

It is beyond the scope of this thesis to make normative judgements about whether imbalances in the literature are good/bad, fair/unfair, etc; it is only possible to observe the existence of imbalance and draw conclusions concerning the implications of this. Paper 3 indicates that the over-emphasis of specific contexts or indicators - "narrating or measuring the history of incremental actions in atomised locations, with emphasis on the specific role of municipalities" - may reduce the scope of analysis or action (Paper 3).

This implies that the literature's tendency to rely on case studies and specific, observed micro-level examples, may distort perceptions of urban sustainability. Pragmatic approaches to research may thus reinforce problems of research, by removing content from frames, or frames from galleries. In other words, the focus on case studies may lead to relativism, in which marginal improvements in relative "sustainability" come to be presented as sustainability, in relation to other worse cases and not in relation to the "big picture". Thus, it is possible to wonder - as the scale of challenges is increasing faster than the scale of achievement and unsustainable development is, in global terms, the norm - whether the scientific study of urban sustainability is actually contributing to the persistence of unsustainable development?

\subsection{Relationship of Papers 1-2 with Paper 3}

Papers 1-2 make contributions towards understanding some of the research challenges identified by Paper 3. Nonetheless, Papers 1-2 do so by making use of the case study method and the possible constraints imposed by this. It is, for example, immediately obvious that the empirical focus is on Swedish municipalities and energy and climate strategies. As such, the study may not appear obviously relevant to researchers working on other national contexts or with a different thematic focus. Moreover, almost all Swedish municipalities are, in global terms, small-medium-sized municipalities. 
Having said this, the use of comparative studies and purposeful sampling means that the sample may be considered reasonably representative of municipalities participating in the Sustainable Municipality programme, and perhaps more generally of other Swedish municipalities. Moreover, the comparative format enables analysis which rapidly reveals the unsuitability of some traditional typologies of municipalities (e.g. population size) for conducting analysis of this kind. Differences between municipal approaches appear to occur independently of such contextual factors. Thus, within the national context, comparative case studies may contribute towards a richer, more nuanced account of organisational processes, strategic planning and participation.

Swedish examples are often referred to in discussions on urban sustainability (see e.g. Granberg and Elander, 2007; Svane et al, 2011). As such, there is a risk that the cases presented in this study appear as "the usual suspects" or reinforce imbalances in the literature (McFarlane, 2010). It is partly for this reason - although there are several others - that the researchers have purposefully avoided describing the observed processes or their outcomes in terms of judgements of good/bad, etc. What appears relevant or good (in terms of reducing unsustainability) in any given context may appear less so in other contexts or the wider global context; moreover, there is no appropriate benchmark against which such claims can be made. In addition, the municipalities studied were at the early stages of implementing their strategies, meaning that few or no results were available to analyse beyond the content of strategies and the experiences of participants. Thus, rather than attempting to impose judgements that would be valueladen, unscientific and possibly highly normative, the researchers chose to observe processes in terms of general characteristics.

This approach may help insulate case studies from some of the risks identified in Paper 3. Moreover, the findings of Papers 1-2 imply that, if traditional typologies are of limited use when comparing cases within contexts, then they may also provide limited insight when comparing cases between contexts. Simply comparing large cities with large cities, small with small, or equivalent, provides limited insight, irrespective of where the cities are located. However, comparison of contexts within or between cases (e.g. in terms of rational or communicative approaches) may help to highlight cases with similar contexts, traditions and tendencies, and thereby enable richer analysis.

\subsection{Relationship of Paper 3 with Papers 1-2}

In such ways, the findings of Paper 3 complement and support the focus of Papers 1-2, whilst posing challenging questions concerning the methodological basis for study. Paper 3 highlights a need for detailed studies of urban sustainability governance and the ways in which municipalities organise strategic planning processes for urban sustainability, in order to better account for issues including organisation structure, procedure, framing and levels of participation. At the same time, Paper 3 cautions 
against over-reliance on the case study as a method for study and highlights a range of potential implications of doing so.

However, Papers 1-2 may provide an interesting riposte to Paper 3. Whilst it may be argued (as Paper 3 does) that extensive use of case studies or exclusive focus on municipalities or particular themes risks reducing the study of urban sustainability to assessment of atomised incrementalism, this need not be inevitable. As Papers 1-2 show, the case study approach may also add to our understanding of municipal strategy processes, by redefining our notions of context and reframing the terms of debate around other characteristics. The specificity of contextual factors mobilised in case study analysis is likely to determine the extent to which it provides relevant and illuminating insights to those working in other contexts. With this in mind, it is time to extend the scope of analysis and synthesise the results of the three papers, with introduction of a new concept that has emanated from these studies - the five factors. 


\section{Synthesis discussion}

The five factors were identified during the course of preparing this thesis and emerge from the findings of the three papers as generalisable factors of importance influencing the approaches used by municipalities to develop energy and climate strategies and contribute to wider urban sustainability initiatives. The choice of five factors was not inevitable, and reflects the outcomes of the studies. Each of the factors is discussed in previous literature, yet the contribution of this thesis is to link them together. As such, the five factors provide a conceptual framework for analysis of urban sustainability processes and complement and develop the idea of rational and communicative approaches studied in Papers 1-2.

The five factors are capacity, mandate, resources, scope and will. The five factors are interdependent and interact, and on occasions, they may appear inseparable. Each of the factors can be understood in narrow terms, e.g. solely concerning municipal organisations, or in a broader sense, as dynamic, having multiple dimensions and involving diverse stakeholders (i.e. in terms of rational or communicative approaches). Each factor may also be understood as an inclusive umbrella term, rather than as exclusive - or excluding - other hypothetical interpretations of what may or may not be influential. To illustrate the five factors, the following short examples are provided. These do not intend to provide comprehensive definitions of each factor, but rather to facilitate understanding of the five factors and their relationship to the results of Papers $1-3$.

Capacity concerns the ability of stakeholders to participate and act in processes and subsequent implementation. Capacity may relate to group or individual competencies or capabilities, in terms of knowledge and understanding, yet may also relate to whether such groups or individuals have the opportunity to participate. Whilst the former point may to some extent interact with will, the latter is clearly related to resources, which may determine or impose restrictions on capacity. Capacity is an issue discussed in the scientific journal articles reviewed in Paper 3 (see e.g. Aguilar and Santos, 2011; or Lindholm and Behrends, 2012), and a recurring point in the case studies of Papers 1-2. For example, in Paper 2, capacity is cited as both a defence for inaction and a reason for action by different municipalities.

Mandate has multiple meanings and may relate to legal, political or social/ethical norms or regulations influencing the perceived or defined scope for action. In its various forms, mandate may provide the entitlement to act, and is closely linked to the issue of legitimacy. Mandate also has an impact upon the internal processes of organisations. For example, in Municipality C (Papers 1-2), the Coordinator of the energy strategy planning process was given a strong mandate to act by local politicians who in turn 
considered themselves to have a strong mandate from the local community. This was less evident in the other municipalities studied in Papers 1-2.

Resources - both in terms of actual resources and perceptions about resources influence processes in numerous ways. For example, time, budget, personnel and information may all be considered as resources. Articles discussed in Paper 3 identify resources as an important influence (see e.g. Jacobi and Besen, 2011), and the issue was discussed extensively by the municipalities studied in Papers 1-2. As with capacity, the availability of resources was used as a justification of both action and inaction, and evidently influential to municipalities employing both rational and communicative approaches to strategic planning processes.

Scope is, like Mandate, related to the legal, institutional, constitutional and organisation contexts framing a process. Whereas Mandate is a means of providing entitlement and claiming legitimacy, scope relates to the opportunity to act and the extent of action. As such, scope interacts with other factors, such as capacity, to influence the scale and direction of a process. The review of scientific journal articles in Paper 3 shows that scope is a critical issue in the field of urban sustainability (see e.g. Ceron Castano and Wadley, 2012; Chester et al, 2012; Seto et al, 2012), and the municipalities in Papers 12 make use of different approaches and reasoning to justify the scope of their processes, with notable differences between those employing rational or communicative approaches.

Will relates partly to the desire of individuals and groups to address the challenge of urban sustainability, and within this, to determine how to do so. Will is thus closely related to scope and mandate, as it influences the extent to which both may be challenged; e.g. by determining the extent to which people are willing to change or modify systems, regulations or norms that pose barriers to actions, and the extent to which people understand the impacts of their actions and are willing to embrace new ideas or substantial changes to the status quo. In Papers 1-2, differences in will are evident in, for example, the reasons motivating processes or the extent to which stakeholders are involved in processes. Such differences influence the extent to which municipalities select rational or communicative approaches for strategic planning processes.

Use of the five factors as an analytical tool may help researchers and practitioners increase their understanding of the underlying structural conditions that influence and shape sustainable development in municipalities (and perhaps also other organisations). This will enable a more nuanced understanding of municipal organisations and municipal processes to develop, and contribute to the emergence of new debates on implications of current municipal approaches. 
Moreover, the factors find support from other authors (i.e. not studied in Papers 1-3). For example, the factors will, resources and capacity are identified as critical by Anderton (2012), who notes the existence of "strategic capacity gaps" (i.e. resources, competence) and "strategy action deficits" (in which ambitions are not translated into deliverable policies) in a study of sub-national government in four countries. Blake (1999) addresses the multidimensionality of the factors and need for redefinition of roles, responsibilities and concepts when discussing the "value-action gap" in urban sustainability.

In another comparative study, Trisolini and Zasloff (2009) highlight the importance of mandate, whereas others discuss scope in a variety of ways. For example, Porter and Reinhardt (2007) refer to the importance of "inside-out" and "outside-in" perspectives for organisational strategy, whereas Seto et al (2012) apply the theoretical concept of teleconnections to urban sustainability, as a way of conceptualising out-of-sight "quantum" effects of unsustainable development, and Seitzinger et al (2012) propose thinking and working "beyond city limits".

An "inside out" perspective involves organisations attempting to understand the full impacts of up- and downstream effects, thereby extending the scope of their analysis (e.g. environmentally, geographically, temporally, but also in terms of partnerships, production and end-use), whereas an "outside in" perspective involves considering the unstable, dynamic operating context and implications of external forces on not only the organisation's scope or mandate to act, but also its capacity, resources and will to act. Porter and Reinhardt note that "firms can address outside-in effects strategically if they can manage them in ways that competitors cannot readily match" (Porter and Reinhardt, 2007, p. 26). From a municipal perspective, this reasoning suggests that municipal organisations should attempt to adopt a strategic approach to urban sustainability and success in doing so will provide competitive advantages, as well as environmental benefits.

The five factors represent a conceptual framework which may contribute to understanding the ways in which municipalities approach urban sustainability, yet many questions remain unresolved by this thesis. How, for example, do the five factors interact with target-setting to determine the extent of municipal ambition and action? Do municipalities rely on other targets, such as those of the Kyoto process, the European Union, or their peers to provide helpful frames for urban sustainability target-setting, or do they set targets in relation to perceived obligations, abilities, needs, or values? Why do municipalities neglect or discount seemingly viable alternatives in the quest for urban sustainability? Or assume flawless implementation of strategies, despite the presence of strategic capacity gaps and strategy action deficits? What can the five factors tell us about such debates, and others? 
An analysis of municipalities using the five factors model should not overlook the multiple and varying roles of municipalities. For example, municipal organisations may be participants in processes, just as they may lead processes, control them or be subject to their outcomes; in other words, they may be the regulated or the regulator, the beneficiary or the claimant, and in some instances, these roles co-exist (Kern and Alber, 2009). Nonetheless, the five factors point towards the need to improve understanding of municipal processes and the decision-making processes of individuals and groups, both those participating in municipal processes and in the wider community. Analysis of such issues may be developed in future studies. 


\section{Conclusions}

This thesis aimed to synthesise findings from three papers in order to develop a conceptual framework that provides new insights into the practical organisation of strategic planning processes in Swedish municipalities and assists researchers and practitioners working on urban sustainability. Three research questions were proposed and responded to in Papers 1-3.

Paper 1 studied how processes to develop energy and climate strategies were organised in five Swedish municipalities participating in the national Sustainable Municipality programme. Results showed the contextual factors influencing the municipalities (such as their relative size) were not necessarily more influential than the extent to which the municipalities employed rational or communicative approaches. Municipalities with more communicative processes were more likely to involve stakeholders in processes earlier and without preconditions, whereas processes were more exclusive in municipalities adopting more rational approaches. The difference in choice of approach impacted upon the both the scope and content of a process and its outcomes. This implies that, in order to comprehensively address multi-dimensional challenges such as energy and climate change, municipalities need to adopt communicative approaches and thereby extend the scope of their strategic planning processes.

These results are complemented by the findings of Paper 2, which studied stakeholder participation in the same processes as Paper 1. Reflecting on the experiences of participants, Paper 2 concludes that active and early engagement of stakeholders in strategic planning is desirable and impacts upon the scope of strategic planning processes. Paper 2 extends the discussion on scopes by proposing a method for conceptualising scopes of influence that, if applied systematically, may help municipalities improve their understanding of the role of other stakeholders, their own ability to cooperate, and enable them to address a wider range of externalities in both their strategies and implementation processes.

Paper 3 provides an overview of a selection of recent scientific journal articles, discussing both the themes and methods used by scholars, as well as the theoretical content of their discussions. Paper 3 notes that the methods used to conduct studies generate certain imbalances in the literature, such as the preponderance of case studies, at the expense of greater variety and perhaps with detrimental impacts on analysis of urban sustainability in both theoretical and practical terms. The literature reviewed in Paper 3 shows the literature emphasises the importance of scope, will and mandate, and to a lesser extent, capacity and resources, without - individually or collectively providing deep elaboration on how to systematically incorporate these factors into a governance framework for urban sustainability. 
In this thesis, the juxtaposition of these papers brings these factors into focus. Papers 1 and 2 contribute to understanding how the general characteristics of strategic planning processes interact with political and legal dynamics. The rational and communicative models explored in Paper 1, and the method for conceptualising scopes proposed in Paper 2, thus provide insight into issues identified as important in the literature review of Paper 3. Similarly, Paper 3 enriches the findings of Papers 1 and 2 by underlining the relevance of their results and placing them in a wider context, whilst simultaneously illuminating aspects of the studies that were not previously given central focus. Together, the Papers illustrate some of the complex challenges and opportunities of urban sustainability practice and research, and attempt to highlight how different approaches to strategic planning processes may relate to such challenges and opportunities.

By synthesising the findings of Papers 1-3, a new conceptual framework emerges - the "five factors" influencing strategic planning processes for urban sustainability in municipalities. These are: capacity, mandate, resources, scope and will. The thesis thereby develops the results of Papers 1-3 to offer a framework for understanding general characteristics that shape and influence strategic planning processes for urban sustainability in municipalities. The five factors emphasise and elaborate the distinction between rational and communicative approaches discussed in Papers 1-2. Moreover, whilst the empirical focus of Papers 1-2 is on Swedish municipalities, the five factors which provide a conceptual framework that aims to improve the comprehensiveness of strategic work - may be relevant to communities in other contexts facing up to similar strategic challenges. This builds upon the findings of Papers 1-2, where significant differences in how five municipalities approach the same issue appear not to depend on contextual factors such as population or size; and Paper 3, that general, non-contextspecific characteristics of municipalities may be neglected in literature on urban sustainability.

The five factors are flexible and multi-dimensional and may help scholars to better account for contextual, individual, group, structural, and systemic issues that enable or constrain processes aiming for urban sustainability. Thus, the role of the five factors in urban sustainability, the relevance of the factors to different stakeholder groups, and the extent to which this framework contributes to understanding differences in municipal approaches to urban sustainability are issues that could be addressed in future studies. 


\section{Future Research}

The five factors represent an interesting contribution to existing literature. Nonetheless, it remains to be seen if and how the concept can be utilised to enhance the quality of strategic processes in municipalities, or indeed, the study of such processes. As yet, the factors are rather more "conceptual" than a "framework". Nevertheless, future research could explore the implications of using the factors in a systematic way, or the consequences of partial or varying levels of strength between the different factors. Future studies could, for example, consider the question of whether weaker or stronger application of the five factors influences the content of outputs such as strategies.

Another important question is: how encompassing are the five factors and how much do they explain? Perhaps in a larger study, some factors would take more prominence than others; possibly non-factors, currently subsumed within the five, would emerge as more relevant, replacing factors or adding to the framework. Similarly, how would the adoption of rational or communicative approaches impact upon the factors? Papers 1 and 2 offered some indications with regard to scope, yet these questions could be considered in more detail. Such issues are only likely to be resolved through systematic study, which in turn requires application in an organisational setting, or the development of indicators. All this is beyond the scope of this thesis, yet may be addressed in future research.

Other research could explore the validity of Papers 1 and 2 by conducting similar case studies, or extend the temporal and methodological scope of Paper 3 to develop its findings. Another possibility is to address an issue alluded to in Paper 3, namely the question of representation in the bodies of literature addressing urban sustainability, and thereby contribute to improving understanding of which cases - and which kinds of sustainability - are presented. As previously noted, there are imbalances, and cases from certain countries - including Sweden - are often perceived as being "the usual suspects" (ICLEI, 2012; McFarlane, 2010). The validity and relevance of findings such as those presented in this thesis may be reinforced by increased diversity in the literature, and more systematic identification of common factors influencing municipal work for urban sustainability. This thesis has attempted to make a contribution to this debate and hopes to inspire future research in this field, yet the work must go on. 


\section{References}

Acuto, M., (2013) The new climate leaders? Review of International Studies, 39, pp. 123.

Aguilar, A.G., Santos, C., (2011) Informal settlements' needs and environmental conservation in Mexico City: An unsolved challenge for land-use policy, Land Use Policy, 28(4), pp. 649-662.

Albrechts, L., (2004) Strategic (spatial) planning reexamined. Environment and Planning B: Planning and Design, 31, pp. 743-758.

Anderton, K., (2012) Sub-national governance and reducing the climate impact of cars, Lund Conference on Earth System Governance. Lund, Sweden, 18-20 April 2012.

Arnott, R.J., (2012) Urban policy: Shedding light on urban policy, Nature Climate Change, 2, pp. 314-315.

Betsill, M., Bulkeley, H., (2007) Looking Back and Thinking Ahead: A Decade of Cities and Climate Change Research, Local Environment: The International Journal of Justice and Sustainability, 12(5), pp. 447-456.

Blake, J., (1999) Overcoming the 'value-action gap' in environmental policy: Tensions between national policy and local experience, Local Environment: The International Journal of Justice and Sustainability, 4(3), pp. 257-278.

Boote, D.N., Beile, P., (2005) Scholars before researchers: On the centrality of the dissertation literature review in research preparation. Educational researcher, 34, pp. 315 .

Brandt, P., Ernst, A., Gralla, F., Luederitz, C., Lang, D.J., Newig, J., Reinert, F., Abson, D.J., von Wehrden, H., (2013) A review of transdisciplinary research in sustainability science, Ecological Economics, 92, pp. 1-15.

Campbell, S., Fainstein, S., (Eds) (2003) Readings in Planning Theory. Malden: Blackwell Publishers.

Ceron Castano, I., Wadley, D., (2012) Conceptualization and System Design in the Monitoring of Urban Form, Planning Practice \& Research, 27(5), pp. 495-511. 
Chester, M., Pincetl, S., Allenby, B., (2012) Avoiding unintended tradeoffs by integrating life-cycle impact assessment with urban metabolism, Current Opinion in Environmental Sustainability, 4(4), pp. 451-457.

Collins, K., Ison, R., (2006). Dare We Jump Off Arnstein's Ladder? Social Learning as a New Policy Paradigm. PATH (Participatory Approaches in Science and Technology) Conference, 4-7 June 2006.

Connelly, S., (2007) Mapping Sustainable Development as a Contested Concept, Local Environment: The International Journal of Justice and Sustainability, 12(3), pp. 259278.

Cook, C., Bakker, K., (2012), Water security: Debating an emerging paradigm, Global Environmental Change, 22(1), pp. 94-102.

Cook, I.R., Swyngedouw, E., (2012) Cities, Social Cohesion and the Environment: Towards a Future Research Agenda, Urban Studies, 49(9), pp. 1959-1979.

Council of European Municipalities and Regions (CEMR), (2009) Local and regional authorities - Balancing democracy, identity and efficiency - Changes in local and regional structures in Europe, Brussels: CEMR.

Creswell, J.W., (2008) Research design: Qualitative, quantitative, and mixed methods approaches. London: Sage Publications.

Crutzen, P.J., Stoermer, E.F., (2000) The 'Anthropocene', Global Change Newsletter, 41, pp. 17-18.

Deleuze, G., Guattari, F., (2003) A Thousand Plateaus: capitalism and schizophrenia, London: Continuum.

Droege P., (Ed.) (2008) Urban Energy Transition: From Fossil Fuels to Renewable Power, Oxford: Elsevier.

Eisenhardt, K.M., Graebner, M.E., (2007) Theory building from cases: Opportunities and Challenges. Academy of Management Journal, 50(1), pp. 25-32.

Emilsson S., Hjelm O., (2009) Towards Sustainability Management Systems in three Swedish Local authorities. Local Environment: The International Journal of Justice and Sustainability, 14(8), pp. 721-732.

European Commission, (2010) How to develop a Sustainable Energy Action Plan (SEAP) - Guidebook, Luxembourg: Publications Office of the European Union. 
Farreny, R., Oliver-Solà, J., Montlleó, M., Escribà, E., Gabarrell, X., Rieradevall, J., (2011) Transition towards sustainable cities: Opportunities, constraints, and strategies in planning. A neighbourhood ecodesign case study in Barcelona, Environment and Planning A, 43(5), pp. 1118-1134.

Fenton, P., Gustafsson, S., Ivner, J., Palm, J., (2012) Sustainable Energy and Climate Strategies: lessons from planning processes in five municipalities. Linköping: Linköping University.

Fink A., (2005) Conducting Research Literature Reviews: From the Internet to Paper. Thousand Oaks: Sage.

Flick, U., (2009) An introduction to qualitative research. London: Sage Publications.

Fredriksson, C., (2011) Planning in the 'New Reality'- Strategic Elements and Approaches in Swedish Municipalities, Doctoral dissertation, Stockholm: KTH.

Gerring, J., (2008) Case Selection for Case-Study Analysis: Qualitative and Quantitative Techniques, in Box-Steffensmeier, J., Brady, H., Collier, D. (Eds.), Oxford Handbook of Political Methodology, Oxford: Oxford University Press, pp. 645-684.

Goertz, G., Mahoney, J., (2006) A Tale of Two Cultures: Contrasting Qualitative and Quantitative Research, Political Analysis, 14(3), pp. 227-249.

Golden-Biddle, K., Locke, K., (2006) Composing qualitative research. London: Sage Publications.

Granberg, M., Elander, I., (2007) Local Governance and Climate Change: Reflections on the Swedish Experience, Local Environment: The International Journal of Justice and Sustainability, 12(5), pp. 537-548.

Grumley, J.E., (1989), History and totality: Radical historicism from Hegel to Foucault, London: Routledge.

Gupta, J., van der Leeuw, K., de Moel, H., (2007) Climate change: a 'glocal' problem requiring 'glocal' action, Environmental Sciences, 4(3), pp. 139-148.

Gustafsson, S., Hjelm O., (2011). Strategiskt och verkningsfullt? Ledningsverktygs bidrag till kommuners hållbarhetsarbete. Rapport 2011:4. Linköping: Centrum för kommunstrategiska studier, Linköping University.

Healey, P., (2009) The pragmatic tradition in planning thought. Journal of Planning Education and Research. 28(3), 277-292. 
Hollander, K., Kamphof, R., Zwart, R., (2012) A survey on urban sustainability. The Hague: European Metropolitan network Institute.

ICLEI, (2012) Local Sustainability 2012: Taking stock and moving forward. Bonn: ICLEI.

Ivner, J., Björklund, A., Dreborg, K.H., Johansson, J., Viklund, P., Wiklund, H., (2010). New Tools in Local Energy Planning: Experimenting with Scenarios, Public Participation and Environmental Assessment, Local Environment: The International Journal of Justice and Sustainability, 15(2), pp. 105-120.

Jacobi, P.R., Besen, G.R., (2011) Gestão de resíduos sólidos em São Paulo: desafios da sustentabilidade, Estudos Avancados, 25(71), pp. 135-158.

Jacobs, M., (1999) Sustainable development as a contested concept. in Dobson, A. (Ed.), Fairness and Futurity: Essays on Environmental Sustainability and Social Justice, Oxford: Oxford University Press, pp. 21-45.

Johnson, D.B., Macy, G., (2001) Using environmental paradigms to understand and change an organization's response to stakeholders, Journal of Organizational Change Management 14 (4), pp. 314-334.

Jukic, B., Jukic, N., Harris, D., (2011) Feasibility frontier-a method for aligning competitive strategy with the choice of it architectures, Journal of Organizational Computing and Electronic Commerce, 21 (2), pp. 158-175.

Kahneman, D., Tversky, A., (1979) Prospect Theory: An Analysis of Decision Under Risk, Econometrica. XLVII, pp. 263-291.

Kern, K., Alber, G., (2009) Governing Climate Change in Cities: Modes of Urban Climate Governance in Multi-level Systems, in Competitive Cities and Climate Change, OECD Conference Proceedings, Milan, Italy, 9-10 October 2008, Paris: OECD, pp. 171-196.

Khakee, A., (1999). Demokrati i Samhällsplaneringen, in Amnå, E. (Ed.), Medborgarnas Erfarenheter, Stockholm: SOU 199:113, pp. 197-218.

King, G., Keohane, R., Verba, S., (1994) Designing Social Inquiry, Princeton: Princeton University Press.

Lee, T.W., Mitchell, T.R., Sablynski, C.J., (1999) Qualitative research in organizational and vocational psychology, 1979-1999, Journal of Vocational Behavior, 55(2), pp. 161187. 
Levidow, L., Oreszczyn, S., (2012) Challenging unsustainable development through research cooperation, Local Environment: The International Journal of Justice and Sustainability, 17(1), pp. 35-56.

Lindholm, M., Behrends, S., (2012) Challenges in urban freight transport planning - a review in the Baltic Sea Region, Journal of Transport Geography, 22, pp. 129-136.

Lundqvist, L.J., Biel, A., (2007) From Kyoto to the Town Hall: Transforming National Strategies into Local and Individual Action, in Lundqvist, L.J., Biel, A. (Eds.), From Kyoto to the town hall: making international and national climate policy work at the local level, London: Earthscan.

McFarlane, C., (2010) The comparative city: knowledge, learning, urbanism. International Journal of Urban and Regional Research, 34(4), pp. 725-742.

Miles, M.B., Huberman, A.M., (1984) Qualitative data analysis: A sourcebook of new methods, Beverly Hills: Sage Publications.

Minoia, P., Calzavara, A., Lovo, L., Zanetto, G., (2009) An assessment of the principle of subsidiarity in urban planning to face climate change - The case of Martellago, Venice Province, International Journal of Climate Change Strategies and Management, 1(1), pp. 63-74.

Mori, K., Christodoulou, A., (2012) Review of sustainability indices and indicators: Towards a new City Sustainability Index (CSI), Environmental Impact Assessment Review, 32(1), pp. 94-106.

Newell, J.P., Seymour, M., Yee, T., Renteria, J., Longcore, T., Wolch, J.R., Shishkovsky, A., (2012) Green Alley Programs: Planning for a sustainable urban infrastructure?, Cities, DOI: 10.1016/j.cities.2012.07.004

Nyseth, T., (2008) Network Governance in Contested Urban Landscapes, Planning Theory \& Practice, 9(4), pp. 497-514.

Polk, M., Knutsson, P., (2008). Participation, Value Rationality and Mutual Learning in Transdisciplinary Knowledge Production for Sustainable Development. Environmental Education Research, 14(6), pp. 643-653.

Polonsky, M.J., (2011) Transformative green marketing: Impediments and opportunities, Journal of Business Research 64 (12), pp.1311-1319.

Porter, L., (2011) The Point is to Change It, Planning Theory \& Practice, 12(4), pp. 477-480. 
Porter M.E., Reinhardt F.L., (2007) A strategic approach to climate, Harvard Business Review, 85 (10), pp. 22-26.

Rashman, L., Withers, E., Hartley, J., (2009) Organizational learning and knowledge in public service organizations: A systematic review of the literature, International Journal of Management Reviews, 11(4), pp. 463-494.

Rosenzweig, C., Solecki, W.D., Hammer, S.A., Mehrota, S., (2011a) Executive Summary, in Rosenzweig, C., Solecki, W.D., Hammer, S.A., Mehrota, S., (Eds.) Climate Change and Cities: First Assessment Report of the Urban Climate Change Research Network, Cambridge: Cambridge University Press.

Rosenzweig, C., Solecki, W.D., Hammer, S.A., Mehrota, S., (2011b) Urban Climate Change in Context, in Rosenzweig, C., Solecki, W.D., Hammer, S.A., Mehrota, S., (Eds.) Climate Change and Cities: First Assessment Report of the Urban Climate Change Research Network, Cambridge: Cambridge University Press.

Rubin, I.S., Rubin, H.J., (2011) Qualitative interviewing: The art of hearing data. London: Sage Publications.

Rydin Y., (2010) Governing for Sustainable Urban Development. London, Earthscan.

Swedish Association of Local Authorities and Regions (SALAR), (2009) Local Action on Climate Change - Swedish Experiences, Stockholm: SALAR.

Swedish Association of Local Authorities and Regions (SALAR), (2012). Classification of Swedish municipalities 2011. Available at:

http://www.skl.se/kommuner_och_landsting/om_kommuner/kommungruppsindelning (accessed 2012-04-24).

Sandhu, S., (2010) Shifting Paradigms in Corporate Environmentalism: From Poachers to Gamekeepers, Business and Society Review, 115 (3), pp. 285-310.

Senge, P.M., Jaworski, J., Otto Scharmer, C., Flowers, B.S., (2005) Presence. Exploring profound change in people, organizations and society. London: Nicholas Brealey Publishing.

Seto, K.C., Reenberg, A., Boone, C.G., Fragkias, M., Haase, D., Langanke, T., Marcotullio, P., Munroe, D.K., Olah, B., Simon, D., (2012) Urban land teleconnections and sustainability, Proceedings of the National Academy of Sciences of the United States of America, 109(20), pp. 7687-7692. 
Seitzinger, S.P., Svedin, U., Crumley, C., Steffen, W., Abdullah, S.A., Alfsen, C., Biermann, F.H.B., Bondre, N.R.,Dearing, J.A., Deutsch, L., Dhakal, S., Elmqvist, T., Farahbakhshazard, N., Gaffney, O., Haberl, H., Lavorel, S., Mbow, C., McMichael, A.J., Morais, J., Olsson , P., Pinho, P., Seto, K.C., Sinclair, P., Stafford-Smith, M., Sugar, L., (2012) Planetary Stewardship in an Urbanizing World: Beyond City Limits, AMBIO, DOI 10.1007/s13280-012-0353-7.

Smith, R., Wiek, A., (2012) Achievements and opportunities in initiating governance for urban sustainability, Environment and Planning C: Government and Policy, 30(3), pp. 429--447.

Svane, Ö., Wangel, J., Engberg, L.A., Palm, J., (2011) Compromise and learning when negotiating sustainabilities: the brownfield development of Hammarby Sjöstad, Stockholm, International Journal of Urban Sustainable Development, 3(2), pp. 141-155.

Swedish Energy Agency / Energimyndigheten, (2011) "The Sustainable Municipality", English webpage: http://www.energimyndigheten.se/en/Sustainability/The-SustainableMunicipality/ (accessed 15 August 2013). Swedish website (2013): http://www.energimyndigheten.se/sv/Offentlig-sektor/uthallig-kommun/ (accessed 5 February 2014).

Thies, C., (2002) A Pragmatic Guide to Qualitative Historical Analysis in the Study of International Relations, International Studies Perspectives 3 (4), pp. 351-72.

Thornley, R.K., (2012) Sustainable strategic alignment of actual project portfolio execution: Application and exploratory case study, 2012 IEEE International Technology Management Conference, ITMC 2012, art. no. 6306411 , pp.374-381.

Trisolini, K., Zasloff, J., (2009) Cities, Land Use, and the Global Commons: Genesis and the Urban Politics of Climate Change, in Burns, W.C.G., Osofsky, H.M. (Eds.), Adjudicating Climate Change. Cambridge: Cambridge University Press, pp. 7298.

United Nations, (2010) Sustainable Development: From Brundtland to Rio 2012, Background Paper* prepared for consideration by the High Level Panel on Global Sustainability at its first meeting, 19 September 2010 (accessed 5 February 2014). http://www.un.org/wcm/webdav/site/climatechange/shared/gsp/docs/GSP16_Background\%20on\%20Sustainable\%20Devt.pdf

United Nations Human Settlements Programme (UN-Habitat), (2011) Cities and Climate Change: Global report on human settlements 2011, London: Earthscan. 
Valentine, S.V., (2010) The green onion: A corporate environmental strategy framework, Corporate Social Responsibility and Environmental Management 17(5), pp. 284-298.

Watson, V., (2003) Conflicting rationalities: implications for planning theory and ethics, Planning Theory \& Practice, 4(4), pp. 395-407.

Webster, J., Watson, R.T., (2002) Analyzing the past to prepare for the future: Writing a literature review, MIS Quarterly, 26, pp. xiii-xxiii.

Wellstead, A.M., Stedman, R.C., (2011) Climate Change Policy Capacity at the SubNational Government Level, Journal of Comparative Policy Analysis: Research and Practice, 13(5), pp. 461-478.

West G., (2010) Integrated sustainability and the underlying threat of urbanization, in Schnellhuber, H-J., Molina, M., Stern, N., Huber, V., Kadner, S. (Eds.), Global Sustainability: A Nobel Cause, Cambridge: Cambridge University Press. pp. 9-18.

World Commission on Environment and Development (WCED), (1987) Our Common Future, Report of the World Commission on Environment and Development. Published as Annex to General Assembly document A/42/427, Development and International Cooperation: Environment.

Williams, K., (2010) Sustainable cities: research and practice challenges, International Journal of Urban Sustainable Development, 1(1-2), pp. 128-132.

Wollmann, H., (2008) Comparing Local Government Reforms in England, Sweden, France and Germany: www.wuestenrot-stiftung.de/download/local-government (accessed 15 January 2014).

Zeemering, E., (2012) Recognising interdependence and defining multi-level governance in city sustainability plans, Local Environment: The International Journal of Justice and Sustainability, 17(4), pp. 409-424. 


\section{Appended Papers}

The articles associated with this thesis have been removed for copyright reasons. For more details about these see:

http://urn.kb.se/resolve?urn=urn:nbn:se:liu:diva-104468 